\title{
Gaseous chemistry and aerosol mechanism developments for version 3.5.1 of the online regional model, WRF-Chem
}

\author{
S. Archer-Nicholls ${ }^{1}$, D. Lowe ${ }^{1}$, S. Utembe ${ }^{2}$, J. Allan ${ }^{1,3}$, R. A. Zaveri ${ }^{4}$, J. D. Fast ${ }^{4}$, Ø. Hodnebrog ${ }^{5, *}$, \\ H. Denier van der Gon ${ }^{6}$, and G. McFiggans ${ }^{1}$ \\ ${ }^{1}$ Centre for Atmospheric Sciences, School of Earth, Atmospheric and Environmental Sciences, \\ University of Manchester, Manchester, UK \\ ${ }^{2}$ School of Earth Sciences, University of Melbourne, Victoria, Australia \\ ${ }^{3}$ National Centre of Atmospheric Science, University of Manchester, Manchester, UK \\ ${ }^{4}$ Atmospheric Sciences and Global Change Division, Pacific Northwest National Laboratory, \\ Richland, Washington, USA \\ ${ }^{5}$ Department of Geosciences, University of Oslo, Norway \\ ${ }^{6}$ Department of Climate, Air, and Sustainability, TNO, Utrecht, the Netherlands \\ *now at: Centre for International climate and Environmental Research-Oslo (CICERO), \\ Oslo, Norway
}

Correspondence to: G. McFiggans (g.mcfiggans@manchester.ac.uk)

Received: 7 January 2014 - Published in Geosci. Model Dev. Discuss.: 22 January 2014

Revised: 18 September 2014 - Accepted: 25 September 2014 - Published: 8 November 2014

\begin{abstract}
We have made a number of developments to the Weather, Research and Forecasting model coupled with Chemistry (WRF-Chem), with the aim of improving model prediction of trace atmospheric gas-phase chemical and aerosol composition, and of interactions between air quality and weather. A reduced form of the Common Reactive Intermediates gas-phase chemical mechanism (CRIv2-R5) has been added, using the Kinetic Pre-Processor (KPP) interface, to enable more explicit simulation of VOC degradation. $\mathrm{N}_{2} \mathrm{O}_{5}$ heterogeneous chemistry has been added to the existing sectional MOSAIC aerosol module, and coupled to both the CRIv2-R5 and existing CBM-Z gas-phase schemes. Modifications have also been made to the sea-spray aerosol emission representation, allowing the inclusion of primary organic material in sea-spray aerosol. We have worked on the European domain, with a particular focus on making the model suitable for the study of nighttime chemistry and oxidation by the nitrate radical in the UK atmosphere. Driven by appropriate emissions, wind fields and chemical boundary conditions, implementation of the different developments are illustrated, using a modified version of WRF-Chem 3.4.1, in order to demonstrate the impact that these changes have
\end{abstract}

in the Northwest European domain. These developments are publicly available in WRF-Chem from version 3.5.1 onwards.

\section{Introduction}

Coupled simulations of atmospheric dynamics, pollutant transport, chemical transformation and mixed-phase processes are challenging because of the complexities of the interactions and feedbacks between these processes. Historically, these systems have been researched in isolation, leading to the development and use of offline chemical transport models (CTMs) that are run offline, driven by atmospheric fields calculated by a previously run meteorological model. CTMs can be used to investigate chemical processes under various prevailing meteorological conditions but do not allow characterisation of the influence of atmospheric composition on meteorology. This limitation has driven the development of online coupled models (Baklanov et al., 2011). 
WRF-Chem is such a fully coupled, "online" regional model with integrated meteorological, gas-phase chemistry and aerosol components (Grell et al., 2005). WRF-Chem is built around the well-established Advanced Research WRF (ARW) core, which handles the meteorology, physics and transport components of the model (Skamarock et al., 2005). Transport of chemical species is calculated using the same prognostic equations, time step and vertical coordinate system used to transport conserved variables in the ARW core model.

The work in this paper has been conducted as part of the ROle of Nighttime chemistry in controlling the Oxidising Capacity Of the atmosphere (RONOCO) campaign. This collaboration of six UK universities aims to better understand nighttime nitrate $\mathrm{NO}_{3}$ radical chemistry, compare its oxidation capacity with that of the daytime hydroxyl $(\mathrm{OH})$ radical and investigate the impacts of multiphase $\mathrm{NO}_{3}$ chemistry on a regional and global scale. WRF-Chem is capable of carrying descriptions of each of the key chemical processes of relevance to RONOCO science, outlined below.

Photolysis of ozone $\left(\mathrm{O}_{3}\right)$ by ultraviolet light at wavelengths below $320 \mathrm{~nm}$ produces excited free oxygen atoms $\left(\mathrm{O}\left({ }^{1} \mathrm{D}\right)\right)$, a fraction of which react with water to create $(\mathrm{OH})$. The $\mathrm{OH}$ radical is highly reactive, reacting with almost all volatile organic compounds (VOCs) to produce organic peroxy radicals $\left(\mathrm{RO}_{2}\right)$ (Atkinson, 2000). In $\mathrm{NO}_{\mathrm{x}}$ $\left(\mathrm{NO}_{\mathrm{x}}=\mathrm{NO}+\mathrm{NO}_{2}\right)$ rich environments, $\mathrm{RO}_{2}$ oxidises $\mathrm{NO}$ via the general reaction

$\mathrm{NO}+\mathrm{RO}_{2} \longrightarrow \mathrm{RO}+\mathrm{NO}_{2}$.

As photolysis of $\mathrm{NO}_{2}$ creates $\mathrm{O}_{3}$, this cycling of $\mathrm{NO}_{\mathrm{x}}$ breaking down VOCs results in a net increase of $\mathrm{O}_{3}$, with the ozone forming potential of the reactions proportional to the VOC chain length (Sheehy et al., 2010). However, $\mathrm{O}_{3}$ is only produced in this process where there is a balance of $\mathrm{NO}_{\mathrm{x}}$ and VOCs (Sillman, 1999). Air parcels saturated with VOCs but low in $\mathrm{NO}_{\mathrm{x}}$ are said to be "NO $\mathrm{x}_{\mathrm{x}}$ sensitive", as a small increase in $\mathrm{NO}_{\mathrm{x}}$ can result in a large increase in $\mathrm{O}_{3}$ production. Likewise, air parcels with low VOC but high $\mathrm{NO}_{\mathrm{x}}$ are said to be "VOC sensitive".

Oxidising agents are required to initiate the breakdown of VOCs to take part in the reactions described above, playing an essential role of "cleaning" the atmosphere of pollutants in the process (Monks, 2005). There are three main oxidants in the troposphere: $\mathrm{OH}, \mathrm{NO}_{3}$, and $\mathrm{O}_{3}$. The $\mathrm{OH}$ radical dominates oxidation during the daytime, but at night its concentration drops and $\mathrm{NO}_{3}$ becomes the primary oxidant (Brown and Stutz, 2012).

The oxidation of VOCs is dominated by $\mathrm{OH}$-initiated reactions. However, $\mathrm{NO}_{3}$ plays a key role controlling the atmospheric burden of certain species with unsaturated double bonds, such as alkenes, monoterpenes, and some sulfur containing compounds, such as dimethyl sulfide (DMS) (Monks, 2005; Allan et al., 2000).
The primary source of $\mathrm{NO}_{3}$ is the reaction of $\mathrm{O}_{3}$ and $\mathrm{NO}_{2}$ (Atkinson, 2000):

$\mathrm{O}_{3}+\mathrm{NO}_{2} \longrightarrow \mathrm{NO}_{3}+\mathrm{O}_{2}$.

During the day it is rapidly photolysed back to $\mathrm{NO}_{\mathrm{x}}$, and also reacts with NO (Asaf et al., 2010). At night, the absence of photolysis and the lower concentrations of $\mathrm{NO}$ allow for the accumulation of $\mathrm{NO}_{3}$. Nighttime mixing ratios of $\mathrm{NO}_{3}$ are typically a few tens of pptv, although peak levels of over 800 pptv have been reported (Asaf et al., 2010). $\mathrm{NO}_{3}$ further reacts with $\mathrm{NO}_{2}$ to form dinitrogen pentoxide $\left(\mathrm{N}_{2} \mathrm{O}_{5}\right) . \mathrm{N}_{2} \mathrm{O}_{5}$ is thermally unstable and readily dissociates back into $\mathrm{NO}_{3}$ and $\mathrm{NO}_{2}$, such that these species settle into a tightly coupled, temperature-dependent equilibrium. With cooler temperatures, or higher levels of $\mathrm{NO}_{2}$, the $\mathrm{N}_{2} \mathrm{O}_{5}: \mathrm{NO}_{3}$ ratio will increase (Osthoff et al., 2007).

There are several loss mechanisms for $\mathrm{N}_{2} \mathrm{O}_{5}$, as described in more detail by Chang et al. (2011). The most significant are thought to be the heterogeneous uptake reactions, whereby $\mathrm{N}_{2} \mathrm{O}_{5}$ is lost to aerosol or cloud particles (Dentener and Crutzen, 1993). The rate at which $\mathrm{N}_{2} \mathrm{O}_{5}$ is processed by heterogeneous uptake is highly dependent on the composition of the aerosol and the ambient humidity (Riemer et al., 2009; Chang et al., 2011). As $\mathrm{NO}_{3}$ and $\mathrm{N}_{2} \mathrm{O}_{5}$ are in equilibrium with each other, direct loss of $\mathrm{N}_{2} \mathrm{O}_{5}$ is an indirect loss mechanism for $\mathrm{NO}_{3}$.

This nighttime oxidant system is tightly coupled and its realistic simulation requires the accurate representation of meteorological conditions, the gas-phase chemistry, and the aerosol loadings and chemical composition. Such a representation in WRF-Chem will enable regional-scale evaluation of:

a. the extent of nighttime $\mathrm{NO}_{3}-\mathrm{VOC}$ chemistry compared to daytime $\mathrm{OH}$-initiated oxidation;

b. the impact of $\mathrm{NO}_{3}$-initiated oxidation on radical budgets, organic products and ozone formation;

c. the relative effect of daytime and nighttime nitrate formation on atmospheric denoxification

d. the effect of aerosol composition on VOC lifetime, of the impact of nighttime chemistry on the regional deposition of oxidised nitrogen.

There are a number of specific requirements for modelling of the UK atmosphere, including those related to comparison of the impacts of nighttime and daytime oxidative chemistry that are the focus of the current work. This paper describes modifications to the process descriptions previously available in the distribution version of WRF-Chem for these purposes. The following three areas provide the focus of the developments:

i. Previous WRF-Chem studies have used substantially reduced chemical schemes. In order to make more comprehensive use of the available emissions data and 
comparison with network measurements, inclusion of a chemical scheme more readily traceable to the Master Chemical Mechanism (MCM, Saunders et al., 2003; Jenkin et al., 2003) is desirable.

ii. $\mathrm{N}_{2} \mathrm{O}_{5}$ heterogeneous chemistry is inadequately represented in the currently available chemistry-aerosol configurations in WRF-Chem. The coupled nighttime oxidant system is of primary interest to the RONOCO project. A parameterised representation of the process has been added to the model.

iii. The contribution to PM in the UK from marine aerosol may be substantial and the policy implications of such uncontrollable PM fractions is important (DEFRA, 2012). Furthermore, $\mathrm{N}_{2} \mathrm{O}_{5}$ heterogeneous uptake is known to be dependent on the chloride content of aqueous aerosol particles and so an accurate representation of the aerosol $\mathrm{Cl}^{-}$burden is required (Thornton et al., 2010). In addition to the inorganic sea-salt, there has been considerable interest in primary marine organic material (O'Dowd et al., 2004). A new sea-spray emissions parameterisation has been developed and included, based on Fuentes et al. (2010), which includes apportionment of some of the aerosol to organic aerosol mass.

Below we will detail the developments that we have made to the gas and aerosol chemical representations within WRFChem. A domain has been configured over the UK to test the changes and make comparisons with the existing CBM-Z chemistry scheme. The detailed emissions available for the UK have been mapped to this domain, and work has been conducted mapping emissions and chemical boundary conditions to the model to create a realistic chemical background. The model has been run to coincide with the summer measurement campaign of the RONOCO project in July 2010. This paper describes the configuration and evaluation of the model, used to compare with measurements as described in detail in the companion paper (Lowe et al., 2014).

All development work discussed in this paper has been applied to version 3.4.1 of the WRF-Chem model, which is the version used for all simulations shown. All developments have been tested and used in fully coupled simulations in both one-way and two-way nested configurations and are available in WRF-Chem distribution version 3.5.1.

\section{WRF-Chem model developments}

WRF-Chem is modular in design and provided with a rapidly expanding choice of gas-phase and aerosol chemical schemes. Gas-phase schemes provided with WRF-Chem include RADM2 (Stockwell et al., 1990, 59 species, 157 reactions), RACM (Stockwell et al., 1997, 73 species, 237 reactions), CBM-Z (Zaveri and Peters, 1999, 73 species, 237 reactions), SAPRC99 (Carter, 2000, 79 species, 235 reactions) and MOZART (Emmons et al., 2010, 85 species and 196 reactions). WRF-Chem is also provided with the capability to add gas-phase chemical schemes, or modify the existing schemes, through the Kinetic Pre-Processor (KPP) interface (Damian et al., 2002). Aerosol modules available in WRF-Chem include the bulk GOCART (Chin et al., 2000), modal MADE-SORGAM (Ackermann et al., 1998; Schell et al., 2001) and MAM (Liu et al., 2012), and sectional MOSAIC (Zaveri et al., 2008) schemes.

WRF-Chem has most widely been used for simulation of the Continental US (see Grell et al., 2011; Ntelekos et al., 2009; Qian et al., 2009). However, it is steadily becoming more widely used in Europe - from regional air quality studies (Solazzo et al., 2012b, a; Tuccella et al., 2012; Ritter et al., 2013), to the impact of emissions from mega-cities (Hodnebrog et al., 2011), the impact of biomass burning and biogenic emissions on elevated ozone levels during a heat wave (Hodnebrog et al., 2012), and the impact of the aerosol direct effect on air quality (Forkel et al., 2012). Most studies have been carried out using the RADM2 gas-phase scheme, coupled with MADE-SORGAM whereby aerosol is included except for Ritter et al. (2013), who use CBM-Z coupled with 4-bin MOSAIC.

\subsection{CRIv2-R5 gas-phase scheme}

Speciated measurements indicate that hundreds of VOCs are emitted from both biogenic and anthropogenic sources (e.g. Guenther et al., 1995; Dore et al., 2003) and many thousands of organic compounds have been isolated in atmospheric samples (Goldstein and Galbally, 2007). These compounds possess a variety of physico-chemical properties because of differences in structure and functional group content. Because these factors influence the reactivity and oxidation pathways, it has long been recognised that the production efficiency of secondary pollutants, such as ozone and secondary organic aerosol (SOA), varies considerably from one compound to another (e.g. Derwent, 1991; Carter, 1994; Grosjean and Seinfeld, 1989). An accurate representation of the degradation of gaseous VOCs is a pre-requisite to reasonable representation of ozone and SOA production.

The MCM v3.1 (Saunders et al., 2003; Jenkin et al., 2003) describes the degradation of 135 emitted VOCs and involves thousands of species and reactions (5900 species and 13500 reactions). While ideal for simulation of larger number of oxygenates, it has not been extensively used in computationally intensive applications such as global and regional 3-D models (the only exceptions being Ying and Li, 2011; Jacobson and Ginnebaugh, 2010). For large-scale coupled models it is generally considered necessary to use reduced schemes with fewer species and reactions.

There are several techniques for reducing the complexity of chemical schemes. Aggregated mechanisms group entire classes of organic compounds as single species carried by the 
chemical scheme (Stockwell et al., 2011). For example, the carbon bond mechanisms (of which CBM-Z is an example) carries the constituent molecular groups separate from the whole molecules, such as PAR (alkane carbon atoms, $>\mathrm{C}<$ ) or OLET (terminal double bonded carbon atoms, $\mathrm{C}=\mathrm{C}$ ) as independent species (Zaveri and Peters, 1999). This can dramatically reduce the total number of species and reactions whilst conserving the number of carbon atoms in the system.

Another method is to use surrogate species with similar chemical properties to represent groups of VOCs. Surrogate schemes are somewhere between explicit and aggregated schemes in nature and complexity (Stockwell et al., 2011). One such scheme is the Common Representative Intermediates, version 2 (CRIv2) (Jenkin et al., 2008). Traceable to the MCM v3.1, the protocol for the development of the CRIv2 scheme is based on the understanding that the total molecular yield of $\mathrm{O}_{3}$ potentially formed as a by-product of a complete $\mathrm{OH}$-initiated and $\mathrm{NO}_{\mathrm{x}}$-catalysed oxidation of a simple hydrocarbon is equivalent to the number of reactive bonds in the parent molecule. This defines the Common Representative Intermediate (CRI) index, based on the number of reactive $\mathrm{C}-\mathrm{C}$ and $\mathrm{C}-\mathrm{H}$ bonds, and represents the total number of $\mathrm{NO}$ to $\mathrm{NO}_{2}$ conversions would occur in the complete oxidation of the parent molecule to $\mathrm{CO}_{2}$ and $\mathrm{H}_{2} \mathrm{O}$. This index is used to define a number of intermediates that represent the breakdown of larger VOCs (Jenkin et al., 2002), reducing the number of intermediates for a given suite of VOCs.

In CRIv2, the mechanism was built on a compound-bycompound basis, continually testing the mechanism against the full MCM, identifying cases where explicit degradation differed from the CRI index approximation and modifying the CRI index appropriately (Jenkin et al., 2008). CRIv2 reduces the number of species and reactions in the MCM v3.1 by around $90 \%$ (to 434 species and 1183 reactions), whilst still describing the degradation of methane and 115 nonmethane VOCs (Jenkin et al., 2008).

By considering a series of emission lumping options for anthropogenic VOCs, a set of five further reduced CRIv2 mechanisms were developed by Watson et al. (2008), with the smallest CRIv2 scheme (known as CRIv2-R5) having 220 species and 609 reactions for the degradation of 22 emitted non-methane VOCs compounds. We have modified the CRIv2-R5 to consider degradation of 26 non-methane VOCs and have implemented it in WRF-Chem. The CRIv2R5 scheme has the advantage over other schemes currently used in 3-D CTMs in that, through its traceability to MCM v3.1, it is also traceable to the results of kinetic and mechanistic studies of atmospheric reactions, and has undergone indirect evaluation against environmental chamber data. For this reason, the CRIv2-R5 mechanism represents a reference benchmark mechanism traceable to our most explicit understanding of atmospheric VOC degradation.

We have used the KPP protocol to include the CRIv2-R5 scheme in WRF-Chem. It has also been coupled to the MOSAIC 4-bin and 8-bin aerosol schemes. Although consider-
Table 1. Computational cost of a single $90 \mathrm{~s}$ time step for different WRF-Chem configurations on the case-study domain. These timings are for the model domain described in the text, running on 160 processors on the HECToR supercomputer.

\begin{tabular}{lc}
\hline Chemistry modules used & Computational cost \\
\hline CBM-Z gas-phase only & $1.6 \mathrm{~s}$ \\
CRIv2-R5 gas-phase only & $4.5 \mathrm{~s}$ \\
CBM-Z and 8-bin MOSAIC & $6.5 \mathrm{~s}$ \\
CRIv2-R5 and 8-bin MOSAIC & $9.5 \mathrm{~s}$ \\
\hline
\end{tabular}

ably more simple than the MCM v3.1, it is the most complex chemical scheme currently in WRF-Chem. We would highlight three main strengths of using the CRIv2-R5 over a simpler mechanism:

i. It is traceable to the MCM, especially with regard to $\mathrm{O}_{3}$ production. It can therefore be used as a benchmark for other schemes.

ii. It explicitly carries many intermediate and species, such as $\mathrm{RO}_{2}$ or organic nitrates. This enables the decoupling of sources and sinks for radicals or the disentangling of different reaction pathways that would be lumped in a simpler mechanism.

iii. The longer chains of VOCs and explicit processing of intermediate species have been shown to produce more $\mathrm{O}_{3}$ in their breakdown in global model studies such as Utembe et al. (2010).

However, it is more expensive to run relative to simpler mechanisms. As a demonstration, we present the computational costs of a $90 \mathrm{~s}$ model time step for the model domain described below on 160 processors on the HECToR supercomputer (http://www.hector.ac.uk/) in Table 1. The CRIv2R5 chemical scheme is approximately $200 \%$ more expensive than CBM-Z. However, the overhead associated with the full 8-bin MOSAIC aerosol module (with aqueous chemistry) is greater than the gas-phase chemistry schemes and use of CRIv2-R5 instead of CBM-Z in our model configuration increases the computational cost by $50 \%$.

For this study, we are interested in the behaviour of the nighttime radical, $\mathrm{NO}_{3}$. As dimethylsulfide (DMS) reacts rapidly with $\mathrm{NO}_{3}$ and may be one of its primary direct loss mechanisms in an oceanic environment, DMS chemistry has been added to the CRIv2-R5 scheme based on von Glasow and Crutzen (2004).

\subsection{Heterogeneous $\mathrm{N}_{2} \mathrm{O}_{5}$ chemistry}

The rates of the major gas-phase reactions to form, and destroy, $\mathrm{NO}_{3}$ and $\mathrm{N}_{2} \mathrm{O}_{5}$, are well known, and these reactions are included in most gas-phase chemical schemes (including CBM- $\mathrm{Z}$ and CRIv2-R5). The heterogeneous uptake of $\mathrm{N}_{2} \mathrm{O}_{5}$ onto aerosol particles is also important, as this reaction acts 
as a sink for $\mathrm{NO}_{\mathrm{x}}$ (Dentener and Crutzen, 1993) and contributes to particulate nitrate (Riemer et al., 2003). However this process is poorly represented (if present at all) in many chemical schemes, and so is the focus of the development work described below.

The $\mathrm{N}_{2} \mathrm{O}_{5}$ heterogeneous reaction has been investigated on materials representing the range of compositions of atmospheric aerosols. The reaction probability $(\gamma)$ has been shown to be dependent principally on the composition and water content (and so atmospheric relative humidity) of these materials. The $\gamma$ is greatest on aqueous solutions of ammonium sulfate or sodium sulfate at high relative humidities (up to $0.04-0.086$ at $76 \% \mathrm{RH})$. Reducing the relative humidity, or adding organics or nitrate to the solutions, suppresses $\gamma$, reducing it by an order of magnitude or more (see Chang et al., 2011, and references therein, for a more complete discussion of these studies). A number of parameterisations of the composition dependence of $\gamma$ have been made. We have chosen to use that of Bertram and Thornton (2009) for this study because it takes into account the contributions of both nitrate and chloride ions to calculation of $\gamma$ - sea-salt and ammonium nitrate aerosol both being common over the UK domain. This scheme will provide an upper bound on the influence of $\mathrm{N}_{2} \mathrm{O}_{5}$ heterogeneous chemistry. In the companion paper to this one (Lowe et al., 2014) we will also investigate the suppression of $\gamma$ by organics using the parameterisation of Riemer et al. (2009).

The reaction mechanism that is used for the hydrolysis of $\mathrm{N}_{2} \mathrm{O}_{5}$ is that of Thornton et al. (2003). They suggest that, after uptake onto the aerosol particle, aqueous phase $\mathrm{N}_{2} \mathrm{O}_{5}$ reacts reversibly with liquid water to form an (as yet unobserved) protonated nitric acid intermediate $\left(\mathrm{H}_{2} \mathrm{ONO}_{2}^{+}\right)$. This then reacts with either liquid water, to form aqueous nitric acid $\left(\mathrm{HNO}_{3}\right)$, or with halide ions to form nitryl halide $\left(\mathrm{XNO}_{2}\right.$; where $\mathrm{X}=\mathrm{Cl}, \mathrm{Br}$, or I):

$$
\begin{aligned}
& \mathrm{N}_{2} \mathrm{O}_{5}(\text { gas }) \rightleftharpoons \mathrm{N}_{2} \mathrm{O}_{5}(\mathrm{aq}) \\
& \mathrm{N}_{2} \mathrm{O}_{5}(\mathrm{aq})+\mathrm{H}_{2} \mathrm{O}(\mathrm{l}) \rightleftharpoons \mathrm{H}_{2} \mathrm{ONO}_{2}^{+}(\mathrm{aq})+\mathrm{NO}_{3}^{-}(\mathrm{aq}) \\
& \mathrm{H}_{2} \mathrm{ONO}_{2}^{+}(\mathrm{aq})+\mathrm{H}_{2} \mathrm{O}(\mathrm{l}) \longrightarrow \mathrm{H}_{3} \mathrm{O}^{+}(\mathrm{aq})+\mathrm{HNO}_{3}(\mathrm{aq}) \\
& \mathrm{H}_{2} \mathrm{ONO}_{2}^{+}(\mathrm{aq})+\mathrm{X}^{-}(\mathrm{aq}) \longrightarrow \mathrm{XNO}_{2}+\mathrm{H}_{2} \mathrm{O}(\mathrm{l})
\end{aligned}
$$

This reaction mechanism has been used by Bertram and Thornton (2009) to interpret the results of laboratory studies made into the reactivity of $\mathrm{N}_{2} \mathrm{O}_{5}$ in aqueous solutions. They have parameterised the reaction probability $(\gamma)$ on how many gas-particle collisions result in the net removal of $\mathrm{N}_{2} \mathrm{O}_{5}$ from the gas-phase in terms of the condensed-phase $\mathrm{H}_{2} \mathrm{O}(1), \mathrm{NO}_{3}^{-}$ and $\mathrm{X}^{-}$abundances.

Heterogeneous uptake of $\mathrm{N}_{2} \mathrm{O}_{5}$ has been added by extending the Adaptive Step Time-Split Euler Method (ASTEM) within the MOSAIC aerosol module (Zaveri et al., 2008). Because we are not modelling any of the intermediate compounds within the Bertram and Thornton (2009) scheme, we assume that $\mathrm{N}_{2} \mathrm{O}_{5}$ is nonvolatile, and that the mass transfer coefficients of $\mathrm{N}_{2} \mathrm{O}_{5}$ for all size bins remain constant over the external ASTEM time step $\left(h_{\text {ASTEM }}\right)$, so that the uptake of $\mathrm{N}_{2} \mathrm{O}_{5}$ can be reduced to a simple first-order process:

$\frac{\mathrm{d} C_{\mathrm{g}, \mathrm{N}_{2} \mathrm{O}_{5}}}{\mathrm{~d} t}=-\left(\sum_{m} k_{\mathrm{N}_{2} \mathrm{O}_{5}, m}\right) C_{\mathrm{g}, \mathrm{N}_{2} \mathrm{O}_{5}}$,

where $C_{\mathrm{g}, \mathrm{N}_{2} \mathrm{O}_{5}}$ is the concentration of $\mathrm{N}_{2} \mathrm{O}_{5}$ in the gas-phase, and $k_{\mathrm{N}_{2} \mathrm{O}_{5}, m}$ is the first-order mass transfer coefficient for $\mathrm{N}_{2} \mathrm{O}_{5}$ over bin $m$, described by Eq. (5) of Zaveri et al. (2008). Integrating the above equation across the time step from the starting time $t$ to the end time $t+h_{\text {ASTEM }}$ gives the new gasphase concentration as

$$
C_{\mathrm{g}, \mathrm{N}_{2} \mathrm{O}_{5}}^{t+h_{\text {STEM }}}=C_{\mathrm{g}, \mathrm{N}_{2} \mathrm{O}_{5}}^{t} \exp \left(-h_{\mathrm{ASTEM}} \times \sum_{m} k_{\mathrm{N}_{2} \mathrm{O}_{5}, m}\right) .
$$

This is equivalent to Eq. (9) in Zaveri et al. (2008). Uptake of $\mathrm{N}_{2} \mathrm{O}_{5}$ to the individual bins, $U_{\mathrm{N}_{2} \mathrm{O}_{5}, m}$, is given by

$$
U_{\mathrm{N}_{2} \mathrm{O}_{5}, m}=\left(C_{\mathrm{g}, \mathrm{N}_{2} \mathrm{O}_{5}}^{t}-C_{\mathrm{g}, \mathrm{N}_{2} \mathrm{O}_{5}}^{t+h_{\mathrm{ATEM}}}\right) \frac{k_{\mathrm{N}_{2} \mathrm{O}_{5}, m}}{\sum_{m} k_{\mathrm{N}_{2} \mathrm{O}_{5}, m}} .
$$

In applying the parameterisation of Bertram and Thornton (2009) we assume that the limiting step is the uptake of $\mathrm{N}_{2} \mathrm{O}_{5}$ to the condensed-phase, and that it reacts in a nearinstantaneous manner with $\mathrm{H}_{2} \mathrm{O}$ and $\mathrm{Cl}^{-}$to give $\mathrm{NO}_{3}^{-}$and $\mathrm{ClNO}_{2}$ through Reactions (R4)-(R6). $\mathrm{ClNO}_{2}$ is not added to the aerosol, but is instead assumed to out-gas in a nearinstantaneous manner, and has instead been added as an extra species to the gas-phase (currently as an inert tracer - no gas-phase reactions involving $\mathrm{ClNO}_{2}$ have been added to the gas-phase chemistry scheme, although this could be added in the future, e.g. following Sarwar et al., 2012). In addition, for simplicity, we assume that the $\mathrm{HNO}_{3}$ molecules formed in Reaction (R5) undergoes ion dissociation to produce aqueous $\mathrm{NO}_{3}^{-}$.

The uptake of $\mathrm{N}_{2} \mathrm{O}_{5}$ is controlled by the reaction probability, $\gamma_{\mathrm{N}_{2} \mathrm{O}_{5}}$, which we use instead of a mass accommodation coefficient in the calculation of the transition regime correction factor (Fuchs and Sutugin, 1971) used in the calculation of $k_{\mathrm{N}_{2} \mathrm{O}_{5}, m}$ (Eqs. 5 and 6 of Zaveri et al., 2008). The reaction probability of $\mathrm{N}_{2} \mathrm{O}_{5}$ has been parameterised by Bertram and Thornton (2009) as

$$
\begin{aligned}
& \gamma_{\mathrm{N}_{2} \mathrm{O}_{5}, m}= \\
& A\left(\beta-\beta e^{-\delta\left[\mathrm{H}_{2} \mathrm{O}\right]_{m}}\right)\left(1-\frac{1}{\frac{k_{3}^{\prime}\left[\mathrm{H}_{2} \mathrm{O}\right]_{m}}{\left[\mathrm{NO}_{3}^{-}\right]_{m}}+1+\frac{k_{4}^{\prime}\left[\mathrm{Cl}^{-}\right]_{m}}{\left[\mathrm{NO}_{3}^{-}\right]_{m}}}\right),
\end{aligned}
$$

where $\left[\mathrm{H}_{2} \mathrm{O}\right]_{m},\left[\mathrm{Cl}^{-}\right]_{m}$ and $\left[\mathrm{NO}_{3}^{-}\right]_{m}$ are the molarities of these compounds within bin $m$; and $A=3.2 \times 10^{-8} \mathrm{~s}, \beta=$ $1.15 \times 10^{6} \mathrm{~s}^{-1}, \delta=1.3 \times 10^{-1} \mathrm{M}^{-1}, k_{3}^{\prime}=6 \times 10^{-2}$ and $k_{4}^{\prime}=$ 29.0 are fitting parameters calculated by Bertram and Thornton (2009). 
The new concentrations of $\mathrm{NO}_{3}^{-}, \mathrm{Cl}^{-}$and $\mathrm{ClNO}_{2}$ are calculated as

$C_{\mathrm{a}, \mathrm{NO}_{3}^{-}, m}^{t+h_{\mathrm{ATEM}}}=C_{\mathrm{a}, \mathrm{NO}_{3}^{-}, m}^{t}+\left(1+f_{\mathrm{NO}_{3}^{-}, m}\right) U_{\mathrm{N}_{2} \mathrm{O}_{5}, m}$

$C_{\mathrm{a}, \mathrm{Cl}^{-}, m}^{t+h_{\mathrm{ASTEM}}}=C_{\mathrm{a}, \mathrm{Cl}^{-}, m}^{t}-f_{\mathrm{Cl}^{-}, m} U_{\mathrm{N}_{2} \mathrm{O}_{5}, m}$

$C_{\mathrm{g}, \mathrm{CINO}_{2}, m}^{t+h_{\mathrm{ASTM}}}=C_{\mathrm{g}, \mathrm{ClNO}_{2}, m}^{t}+f_{\mathrm{Cl}^{-}, m} U_{\mathrm{N}_{2} \mathrm{O}_{5}, m}$

where $f_{\mathrm{NO}_{3}^{-}, m}$ is the fraction of the intermediate species $\mathrm{H}_{2} \mathrm{ONO}_{2}^{+}$postulated by Bertram and Thornton (2009) which reacts with $\mathrm{H}_{2} \mathrm{O}$ (l) to give $\mathrm{HNO}_{3}$ (aq) (or, within the MOSAIC framework, $\left.\mathrm{NO}_{3}^{-}\right)$in bin $m$, and $f_{\mathrm{Cl}^{-}, m}=1-f_{\mathrm{NO}_{3}^{-}, m}$ where

$f_{\mathrm{NO}_{3}^{-}, m}=\frac{1}{1+\frac{k_{4}^{\prime}\left[\mathrm{Cl}^{-}\right]_{m}}{k_{3}^{\prime}\left[\mathrm{H}_{2} \mathrm{O}\right]_{m}}}$.

The above equations are equivalent to Eq. (10) in Zaveri et al. (2008).

Equation (6) is checked to ensure that $C_{\mathrm{a}, \mathrm{Cl}^{-}, m}^{t+h_{\mathrm{ASTM}}}$ never becomes negative; where this would occur we calculate the concentrations at time $t+h_{\text {ASTEM }}$ as

$C_{\mathrm{a}, \mathrm{NO}_{3}^{-}, m}^{t+h_{\mathrm{ASTM}}}=C_{\mathrm{a}, \mathrm{NO}_{3}^{-}, m}^{t}+2 U_{\mathrm{N}_{2} \mathrm{O}_{5}, m}-C_{\mathrm{a}, \mathrm{Cl}^{-}, m}^{t}$

$C_{\mathrm{a}, \mathrm{Cl}^{-}, m}^{t+h_{\mathrm{ASTM}}}=0$

$C_{\mathrm{g}, \mathrm{ClNO}_{2}, m}^{t+h_{\mathrm{ASTEM}}}=C_{\mathrm{g}, \mathrm{ClNO}_{2}, m}^{t}+C_{\mathrm{a}, \mathrm{Cl}^{-}, m}^{t}$

The uptake of $\mathrm{N}_{2} \mathrm{O}_{5}$ is carried out at the same time as the uptake of the involatile gases $\mathrm{H}_{2} \mathrm{SO}_{4}$ and MSA. The change in $\mathrm{NO}_{3}^{-}$and $\mathrm{Cl}^{-}$content of the aerosol is taken into account when estimating the amount of $\mathrm{NH}_{3}$ which is allowed to condense with these involatile acids by modifying Eq. (11) of Zaveri et al. (2008) to

$$
\begin{aligned}
& C_{\mathrm{a}, \mathrm{NH}_{4}, m}^{t+h_{\mathrm{ASTEM}}}=C_{\mathrm{a}, \mathrm{NH}}^{t}, m \\
& +\min \left(\left(2 \Delta C_{\mathrm{a}, \mathrm{SULF}, m}^{t+h_{4}, m}+\Delta C_{\mathrm{a}, \mathrm{CH}_{3} \mathrm{SO}_{3}, m}^{t+h_{\mathrm{ASTEM}}}\right.\right. \\
& \left.\left.+\Delta C_{\mathrm{a}, \mathrm{NO}_{3}, m}^{t+h_{\mathrm{ASTEM}}}+\Delta C_{\mathrm{a}, \mathrm{Cl}, m}^{t+h_{\mathrm{ASTEM}}}\right), \Delta C_{\mathrm{a}, \mathrm{NH}, m}^{\max }\right) .
\end{aligned}
$$

Once the new particle-phase SULF, $\mathrm{CH}_{3} \mathrm{SO}_{3}, \mathrm{NO}_{3}^{-}, \mathrm{Cl}^{-}$, and $\mathrm{NH}_{4}^{+}$concentrations are computed then the internal solid-liquid phase equilibrium in each size bin is updated by the thermodynamic module MESA as in the standard MOSAIC module. The total gas- plus particle-phase species concentrations (Eq. 22 of Zaveri et al., 2008) required for the condensation/evaporation of semi-volatiles $\mathrm{HNO}_{3}, \mathrm{HCl}$, and $\mathrm{NH}_{3}$ are also recalculated at this point, in order to account for the change in aerosol composition after the heterogeneous uptake of $\mathrm{N}_{2} \mathrm{O}_{5}$.

It should be noted that heterogeneous uptake is only simulated for deliquesced aerosol particles and there are currently no in-cloud reactions. This limits the application of the model to largely cloud-free conditions and their inclusion should be the focus of further work.
Table 2. Fractional POA content of sea-salt emissions across the 8 MOSAIC size bins given in Table 3.

\begin{tabular}{cccccccc}
\hline Bin 1 & Bin 2 & Bin 3 & Bin 4 & Bin 5 & Bin 6 & Bin 7 & Bin 8 \\
\hline \multicolumn{2}{c}{ Low Activity } \\
0.05 & 0.05 & 0.0 & 0.0 & 0.0 & 0.0 & 0.0 & 0.0 \\
\hline \multicolumn{2}{l}{ High Activity } \\
0.1 & 0.1 & 0.05 & 0.01 & 0.01 & 0.01 & 0.01 & 0.01 \\
\hline
\end{tabular}

Table 3. Eight-bin MOSAIC size grid.

\begin{tabular}{cl}
\hline $\begin{array}{c}\text { Bin } \\
\text { number }\end{array}$ & $\begin{array}{l}\text { Particle dry diameter } \\
(\mu \mathrm{m})\end{array}$ \\
\hline 1 & $3.90625 \times 10^{-2}-7.8125 \times 10^{-2}$ \\
2 & $7.8125 \times 10^{-2}-1.5625 \times 10^{-1}$ \\
3 & $1.5625 \times 10^{-1}-3.125 \times 10^{-1}$ \\
4 & $3.125 \times 10^{-1}-6.25 \times 10^{-1}$ \\
5 & $6.25 \times 10^{-1}-1.25 \times 10^{0}$ \\
6 & $1.25 \times 10^{0}-2.50 \times 10^{0}$ \\
7 & $2.50 \times 10^{0}-5.00 \times 10^{0}$ \\
8 & $5.00 \times 10^{0}-10.0 \times 10^{0}$ \\
\hline
\end{tabular}

\subsection{Marine organic aerosol}

The current sea-spray emission scheme within the MOSAIC module of WRF-Chem is based on Gong et al. (1997). This parameterisation over-estimates the production of smaller particles (see Gong, 2003; de Leeuw et al., 2011), and so has been modified with a reduction in the source term for particles below a dry diameter of $200 \mathrm{~nm}$ based on the seasalt measurements of O'Dowd et al. (1997). In order to better represent the source term for these smaller particles, Fuentes et al. $(2010,2011)$ have investigated the influence of dissolved organic matter on the production of submicron sea-spray aerosol. They parameterised the sea-spray size distribution (Eqs. 2-4 of Fuentes et al., 2010) over the size range of 3-450 nm dry diameter in terms of the seawater diatomaceous bioexudate organic carbon concentration $\left(\mathrm{OC}_{<0.2 \mu \mathrm{m}}\right)$. We use their parameterisation for sea-spray emissions up to a dry diameter of $450 \mathrm{~nm}$, while above this size we continue to use the scheme of Gong et al. (1997). For this study we have chosen two biogenic activity scenarios: a low-biogenic activity scenario, with $\mathrm{OC}_{<0.2 \mu \mathrm{m}}=0 \mu \mathrm{M}$; and a high-biogenic activity scenario, with $\mathrm{OC}_{<0.2 \mu \mathrm{m}}=$ $280 \mu \mathrm{M}$ (see Lee et al., 2010).

The composition of the inorganic phase of the particles is the same as the previous scheme. However, we also allow for the inclusion of an organic phase, based on a measurement of biogenic activity. The emitted organic phase is simply included as primary organic matter (OM) at present and is reasonably assumed involatile as evidenced by the high molecular weight derived in the Fuentes et al. study. In this study, we use the size-resolved mass fractions for the low- and high- 
biogenic activity scenarios given in Table 2 . The size dependence of the organic mass fraction is estimated from Fig. 7 of de Leeuw et al. (2011) (based on O'Dowd et al., 2004), while the magnitude of the mass fraction is estimated from Fig. 5 of Fuentes et al. (2011) (assuming concentrations of 0 and $2 \mu \mathrm{g} \mathrm{L}^{-1} \mathrm{Chl} a$ for the low- and high-biogenic activity scenarios respectively).

\section{Model domain setup}

For this study, we used a single domain, with a $15 \mathrm{~km}$ horizontal grid spacing and a size of $134(\mathrm{E}-\mathrm{W})$ by $146(\mathrm{~N}-\mathrm{S})$ grid points, shown in Fig. 1. Forty-one vertical model levels are used, with enhanced resolution in the near-surface and planetary boundary layer, after Beck et al. (2013). Each scenario was run from 00:00 UTC, 10 July 2010 to 12:00 UTC, 30 July 2010. The time and location of the domain was chosen to coincide with the RONOCO summer flight campaign, which was principally over the UK and the North Sea. Comparisons between these model results and the aircraft measurements will be made in the companion paper (Lowe et al., 2014).

Meteorological boundary conditions were taken from ECMWF ERA-Interim reanalysis data (Dee et al., 2011), downloaded from the ECMWF data server (http://data-portal.ecmwf.int/). Following an investigation into the evolution of the meteorological fields in the domain using WRF simulations, the internal domain was found to diverge sharply from the ECMWF reanalysis data driving the boundaries shortly after 21 July. To counter this, the meteorology was restarted from ECMWF fields at 00:00 UTC on 21 July 2010. Chemical and aerosol tracers were carried across from the previous model runs when the meteorology was restarted in this way. The remainder of the campaign period was found to evolve in line with the ECMWF data, and so further meteorological restarts were not considered necessary.

\subsection{Emissions}

Emissions are taken from the UK National Atmospheric Emissions Inventory (NAEI) (http:naei.defra.gov.uk) and the TNO emissions inventory. Both inventories provide spatial distributions of gas-phase $\left(\mathrm{NO}_{\mathrm{x}}, \mathrm{CO}, \mathrm{CH}_{4}, \mathrm{SO}_{2}, \mathrm{NH}_{3}\right.$, NMVOCs) and particulate $\left(\mathrm{PM}_{2.5}\right.$ and $\left.\mathrm{PM}_{10}\right)$ emissions. The data are further disaggregated into 11 UNECE source sectors: combustion in energy production and transfer; combustion in commercial institutions, residential and agricultural sectors; combustion in industry; production processes; extraction or distribution of fossil fuels; solvent use; road transport; and other transport.

The NAEI database covers the UK at a resolution of $1 \mathrm{~km} \times 1 \mathrm{~km}-$ we use the 2008 database for this work. The TNO database covers all of Europe at a resolution of $0.125^{\circ}$ longitude by $0.0625^{\circ}$ latitude - for this work we use the 2005 database (Denier van der Gon et al., 2010). We also use TNO databases for particulate emissions of black carbon, elemental carbon and organic carbon which are part of the PanEuropean Carbonaceous aerosol inventory (from deliverable 42 of the EUCAARI project), Kulmala et al. (2011). $\mathrm{NO}_{\mathrm{x}}$ emissions are speciated as $\mathrm{NO} .5 \%$ of $\mathrm{SO}_{2}$ emissions are partitioned into sulfate aerosol (Chin et al., 2000; Simpson et al., 2003).

The speciation of NMVOCs is taken from Watson et al. (2008). As the CBM-Z scheme carries a reduced number of chemical species compared to CRIv2-R5, the 25 emitted CRI NMVOCs have been lumped to $13 \mathrm{CBM}-\mathrm{Z}$ species, as shown in Table 4. Care was taken to conserve the carbon bonds in converting the emissions of NMVOCs from CRI to CBM-Z speciation, resulting in added emissions of the lumped surrogate species "PAR", representing paraffin carbon atoms in higher alkanes and other NMVOCs, following Table 10 of Zaveri and Peters (1999). The only emitted species we were not able to adequately do this for was Ethyne $\left(\mathrm{C}_{2} \mathrm{H}_{2}\right)$, as the triple bond is not carried in CBM-Z. Instead this is emitted as 2 PAR, in order to conserve carbon atoms.

Using scripts developed by Hodnebrog et al. (2012), the emissions were reapportioned to the model grid and scaled by monthly, day of the week, and hourly scaling factors to create 24 emission files for each day. Vertical distribution profiles for each source sector are assumed according to EMEP (2003). The NAEI database is used over the UK (and for shipping emissions around the shores of the UK) while the TNO database is used for mainland Europe, the Republic of Ireland, and shipping emissions around the rest of Europe.

Maps of anthropogenic emissions are shown in Fig. 1a and $b$. There is a mix of $\mathrm{NO}_{\mathrm{x}}$ and VOC emissions from the cities of UK and mainland Europe. There are also significant $\mathrm{NO}_{\mathrm{x}}$ and $\mathrm{SO}_{2}$ emissions from shipping in the Atlantic and the English Channel, while peak VOC emissions are from oil platforms in the North Sea.

Aerosol size distributions for the black carbon $(<1 \mu \mathrm{m})$, organic aerosol from domestic combustion $(<2.5 \mu \mathrm{m})$, and organic aerosol from traffic (and other emissions) $(<2.5 \mu \mathrm{m})$ are calculated from log-normal fits made to measurement data. The data used for black carbon are taken from a UK measurement campaign conducted using the SP2 instrument at Chilbolton as part of the APPRAISE-CLOUDS campaign in 2009. For organic aerosol, wintertime AMS data from Manchester taken in 2007 (Allan et al., 2010) and Holme Moss in 2006 (Liu et al., 2011) were used, with the mass spectral marker peaks at $m / z 57$ and 60 taken as proxies for traffic and domestic combustion respectively. Note that these measurements are deliberately taken at "background" sites, so that the primary emissions will have undergone a degree of ageing before measurement. This gives size distributions that are more suitable for representing aerosol mixtures from heterogeneous sources across the area of a model grid cell. The mode diameter, and distribution width, for each of these 

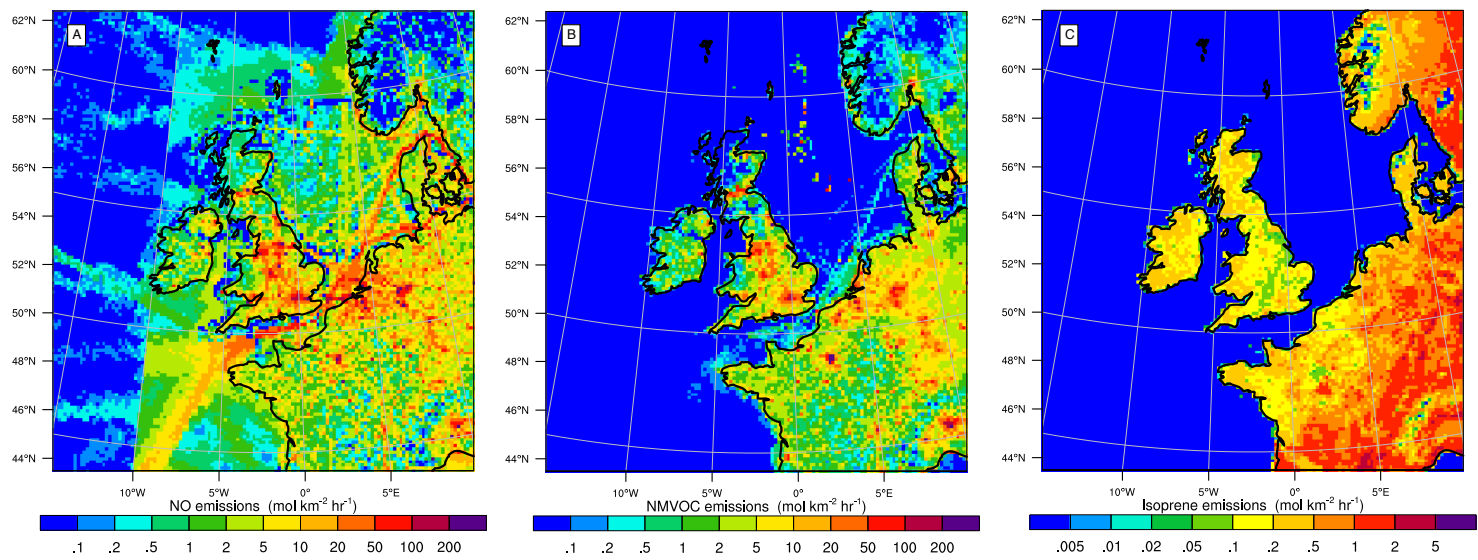

Figure 1. Emissions at 12:00 UTC on 16 July 2010 for: (a) NO; (b) VOCs; and (c) isoprene. NO and VOC emissions are from the merged TNO/NAEI databases. Isoprene emissions are generated online using the MEGAN2 scheme.

Table 4. List of emitted VOC species for CRIv2R5 and CBM-Z, as a fraction of total VOC emissions. Emission factors, by mass, based on NAEI emissions of 124 VOC species (Utembe et al., 2005), reduced to 25 CRIv5-R5 species by Watson et al. (2008). Mappings to CBM-Z variables made according to representation described in Table 10 of Zaveri and Peters (1999).

\begin{tabular}{|c|c|c|c|}
\hline Name of VOC & CRIv2-R5 & CBM-Z & VOC fraction \\
\hline Ethane & $\mathrm{C} 2 \mathrm{H} 6$ & ETH & $2.47 \%$ \\
\hline Propane & $\mathrm{C} 3 \mathrm{H} 8$ & $3 \times$ PAR & $4.29 \%$ \\
\hline Butane & NC4H10 & $4 \times$ PAR & $39.9 \%$ \\
\hline Ethene & $\mathrm{C} 2 \mathrm{H} 4$ & OL2 & $3.15 \%$ \\
\hline Propene & C3H6 & $\mathrm{OLT}+\mathrm{PAR}$ & $1.48 \%$ \\
\hline Trans-2-butene & TBUT2ENE & $\mathrm{OLI}+2 \times \mathrm{PAR}$ & $3.37 \%$ \\
\hline Ethyne & $\mathrm{C} 2 \mathrm{H} 2$ & $2 \times \mathrm{PAR}$ & $1.20 \%$ \\
\hline Formaldyhyde & $\mathrm{HCHO}$ & $\mathrm{HCHO}$ & $1.33 \%$ \\
\hline Ethanal & $\mathrm{CH} 3 \mathrm{CHO}$ & ALD & $0.13 \%$ \\
\hline Propanal & $\mathrm{C} 2 \mathrm{H} 5 \mathrm{CHO}$ & $\mathrm{ALD}+\mathrm{PAR}$ & $0.209 \%$ \\
\hline Acetone & KET & KET & $1.15 \%$ \\
\hline Methyl ethyl ketone & MEK & $\mathrm{KET}+\mathrm{PAR}$ & $1.66 \%$ \\
\hline Methanol & $\mathrm{CH} 3 \mathrm{OH}$ & $\mathrm{CH} 3 \mathrm{OH}$ & $1.16 \%$ \\
\hline Ethanol & $\mathrm{C} 2 \mathrm{H} 5 \mathrm{OH}$ & $\mathrm{C} 2 \mathrm{H} 5 \mathrm{OH}$ & $13.4 \%$ \\
\hline Acetic acid & $\mathrm{CH} 3 \mathrm{CO} 2 \mathrm{H}$ & ORA2 & $0.138 \%$ \\
\hline Benzene & BENZENE & TOL (-PAR) & $2.02 \%$ \\
\hline Toluene & TOLUENE & TOL & $5.82 \%$ \\
\hline$o$-Xylene & OXYL & XYL & $8.54 \%$ \\
\hline 1,2,3-Trimethylbenzene & TM123B & XYL + PAR & $0.355 \%$ \\
\hline 1,2,4-Trimethylbenzene & TM124B & XYL + PAR & $1.18 \%$ \\
\hline Mesitylene & TM135B & XYL + PAR & $0.408 \%$ \\
\hline 2-Ethyltoluene & OETHTOL & XYL + PAR & $0.324 \%$ \\
\hline 3-Ethyltoluene & METHTOL & XYL + PAR & $0.514 \%$ \\
\hline 4-Ethyltoluene & PETHTOL & XYL + PAR & $0.452 \%$ \\
\hline 1,3-Dimethyl-5-ethylbenzene & DIME35EB & $\mathrm{XYL}+2 \times \mathrm{PAR}$ & $0.926 \%$ \\
\hline
\end{tabular}

fits are given in Table 5. These fits are reduced to zero for size bins whose lower edges are greater than 1 micron. The elemental carbon $(1-2.5 \mu \mathrm{m})$ emissions have been apportioned between the fifth and sixth largest size bins (which contain the size range $1-2.5 \mu \mathrm{m}$ ), with the fractions 0.4 and 0.6 respectively (see Table 6). Emissions of particles larger than $2.5 \mu \mathrm{m}$ are apportioned using the default coarse mode frac- tions in the MOSAIC aerosol emission code in WRF-Chem v3.4.1.

Biogenic emissions were calculated "on-line" using the Model of Emissions of Gases and Aerosols from Nature (MEGAN) V2.04 (Guenther et al., 2006; Sakulyanontvittaya et al., 2008). Emissions use a $1 \mathrm{~km} \times 1 \mathrm{~km}$ resolution map of vegetation to derive leaf area index (LAI), which 
Table 5. Log normal mass distributions used for aerosol emissions.

\begin{tabular}{ccc}
\hline Source & $\begin{array}{c}\text { Mode diameter } \\
(\mu \mathrm{m})\end{array}$ & Width \\
\hline $\mathrm{SP} 2 \mathrm{BC}$ & 0.170 & 1.6 \\
$m / z 57$ & 0.360 & 2.4 \\
$m / z 60$ & 0.340 & 1.8 \\
\hline
\end{tabular}

is interpolated to the WRF-Chem model grid and scaled online to calculate the emission rate of isoprene and other emitted species, using model-derived ambient solar radiance, temperature, humidity, wind speed and other physical factors (Guenther et al., 2006). MEGAN2 species are already mapped to CBM-Z variables within WRF-Chem; for this work we have also added mappings to CRIv2-R5 variables. The emissions for CBM-Z have a simpler speciation compared to CRIv2-R5; for example while monoterpene emissions are mapped to either $\alpha$-pinene or $\beta$-pinene in CRIv2R5 they are emitted as isoprene in CBM-Z, with one mole of monoterpene emitted as two moles of isoprene. A map of typical midday isoprene emissions over the domain is shown in Fig. 1c.

\subsection{Lateral boundary conditions}

While regional models can benefit from increased spatial resolution compared to global modelling studies, they require high-quality lateral boundary conditions to function. These are needed both to drive the meteorology and for realistic chemical and aerosol loadings, as pollutants from many large emissions sources that fall outside of the domain boundaries are transported into the region of interest. Typically, these are generated from global model runs and interpolated at the boundaries of the regional model (Giorgi, 1997). For this study, we have used European Centre for Medium Range Weather Forecasts (ECMWF) ERA-Interim reanalysis data (Tavolato and Isaksen, 2011) to drive the meteorology.

For WRF-Chem runs, data from the global Model for Ozone and Related Chemical Tracers (MOZART-4) are frequently used for lateral chemical boundary conditions (Emmons et al., 2010). They provide fields for all of the MOZART-4 chemical tracers, as well as bulk aerosol loadings for sulfate, ammonium nitrate, organic carbon and black carbon. Sea-salt and dust loadings are carried in sectional size bins. The mozbc tool is freely available for interpolating MOZART-4 products onto WRF-Chem domain lateral boundaries, using species mappings for the various chemical schemes in WRF-Chem, such as CBM-Z, as described by Emmons et al. (2010). MOZART-4 data and the mapping scripts can be downloaded from the www.acd.ucar.edu/ wrf-chem website. We have extended the mappings to include the species in the CRIv2-R5 scheme and be internally consistent with emissions mapping for CBM-Z, as described in Table 7.
More recently, the MACC (Monitoring Atmospheric Composition and Climate) project has developed a reanalysis product that is ideal for use in regional coupled model (Stein et al., 2012; Inness et al., 2013). This uses the MOZART3 chemical transport model with the ECMWF Integrated Forecast System (IFS), which has been expanded to integrate measurements of reactive gases, greenhouse gases and aerosol to the ECMWF 4D-Var assimilation system (see Inness et al., 2013, and references therein). The aerosol scheme carries bulk aerosol loadings for sulfate, black carbon and organic particulate, with three size bins for sea-salt and dust aerosol (Morcrette et al., 2009). MODIS retrievals of aerosol optical depth at $550 \mathrm{~nm}$ are used to constrain modelled aerosol, improving its spatial distribution (Benedetti et al., 2009). The gas-phase chemistry is similar to that of the MOZART-4 model, although only a limited number of species are available in the MACC product.

For this study, we have chosen to use a hybridisation of the MACC and MOZART-4 boundary conditions in order to benefit from the better aerosol spatial distribution in the MACC model whilst retaining the more detailed MOZART VOC speciation. Given the relatively small size of our domain, and the detail of the CRIv2R5 chemical scheme, we felt it was important to have information of a broad range of VOC species at our model boundaries. We therefore used the MOZART-4 product for all of our gas-phase chemical boundary conditions and MACC for all available aerosol species. The MACC sulfate aerosol product has been speciated as a mix of $60 \%$ (by mass) $\left(\mathrm{NH}_{4}\right)_{2} \mathrm{SO}_{4}$ and $40 \%$ $\mathrm{NH}_{4} \mathrm{NO}_{3}$ (more consistent with measured aerosol compositions, see Díaz et al., 2006; Morgan et al., 2010).

\section{Analysis of model results}

We calculate an "other inorganic" (OIN) fraction for the particulate emissions by subtracting the sum of the emitted organic and black carbon aerosol mass from the $\mathrm{PM}_{2.5}$ emissions. To avoid errors from mismatches between the different databases used we remove any negative values of OIN which may occur from using this method. The OIN fraction is distributed across the size bins using the default fine-mode fractions in the MOSAIC aerosol emission code in WRF-Chem v3.4.1.

For this study we use a constant oceanic DMS concentration of $2 \mathrm{nML}^{-1}$ when calculating DMS emissions, to represent a low-level background activity (estimated from the database of Kettle et al., 1999).

\subsection{Comparison of daytime and nighttime chemistry in CRIv2-R5 and CBM-Z}

The CRIv2-R5 scheme compares very well (predicted ozone concentrations generally deviate by less than $5 \%$ across a wide range of VOC: $\mathrm{NO}_{\mathrm{x}}$ ratios) against the Master Chem- 
Table 6. Fractional apportionment of particulate emissions across the eight MOSAIC size bins given in Table 3.

\begin{tabular}{|c|c|c|c|c|c|c|c|}
\hline Bin 1 & Bin 2 & Bin 3 & $\operatorname{Bin} 4$ & Bin 5 & Bin 6 & Bin 7 & $\operatorname{Bin} 8$ \\
\hline \multicolumn{8}{|c|}{ TNO black carbon $<1 \mu \mathrm{m}$} \\
\hline 0.0494 & 0.3795 & 0.4714 & 0.0967 & 0.003 & 0.0 & 0.0 & 0.0 \\
\hline \multicolumn{8}{|c|}{ TNO elemental carbon $1 \mu \mathrm{m}-2.5 \mu \mathrm{m}$} \\
\hline 0.0 & 0.0 & 0.0 & 0.0 & 0.4 & 0.6 & 0.0 & 0.0 \\
\hline \multicolumn{8}{|c|}{ TNO organic carbon $<2.5 \mu \mathrm{m}$ (domestic combustion) } \\
\hline 0.0358 & 0.1325 & 0.2704 & 0.3502 & 0.1904 & 0.0657 & 0.0 & 0.0 \\
\hline \multicolumn{8}{|c|}{ TNO organic carbon $<2.5 \mu \mathrm{m}$ (traffic and other sources) } \\
\hline 0.0063 & 0.0877 & 0.3496 & 0.4054 & 0.1376 & 0.0134 & 0.0 & 0.0 \\
\hline
\end{tabular}
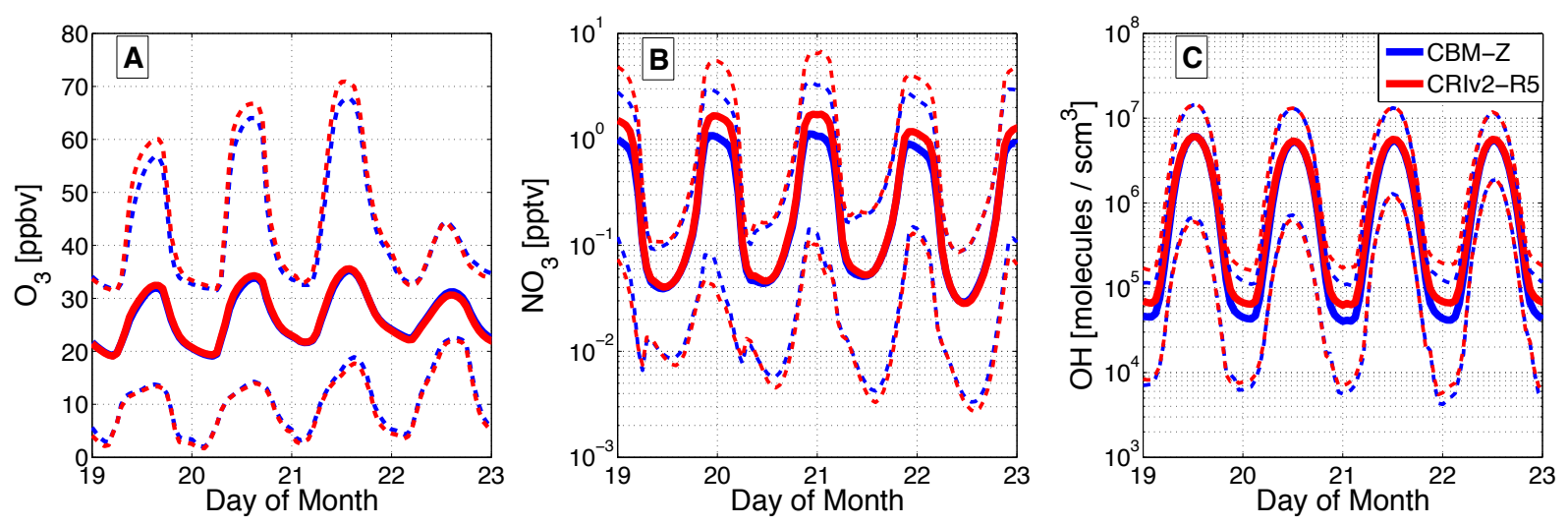

Figure 2. Time series of mixing ratios of key tropospheric oxidants $\mathrm{O}_{3}(\mathbf{a}), \mathrm{NO}_{3}(\mathbf{b})$ and $\mathrm{OH}(\mathbf{c})$. Data from ground level over entire domain, minus the 10 grid points nearest the boundary, covering four days between 00:00 UTC on 19 July 2010 and 00:00 UTC on 23 July 2010. Solid lines show median value, finer dashed lines show 5th and 95th percentiles. Model runs using CBM-Z gas-phase chemistry (blue) and CRIv2-R5 (red). Statistical information used to generate figure has been included in the Supplement.

ical Mechanism (against which it is optimised) within box models along trajectory simulations (Jenkin et al., 2008; Watson et al., 2008). It has also been successfully run under global (3-D) conditions, such as in the Met Office's STOchastic CHEMistry (STOCHEM), where it was found to greatly enhance $\mathrm{O}_{3}$ production compared to the STOCHEM scheme (Utembe et al., 2010). However, to our knowledge, this is the first time it has been applied in a regional 3-D model such as WRF-Chem.

In order to assess the performance of the scheme within WRF-Chem, we compare it against the widely used Carbon Bond Mechanism version Z (CBM-Z) (Zaveri and Peters, 1999; Fast et al., 2006). We have modified the release version of CBM-Z, adding DMS chemistry, and removing reactions for $\mathrm{NO}_{3}$ and $\mathrm{N}_{2} \mathrm{O}_{5}$ (see Appendix A for details).

This comparison focuses on a short period in the middle of the run, between 19 and 23 July 2010. This period was chosen as it covers an interesting pollution episode which occurred over the 20 and 21 July. Over this period, a highpressure system over the UK resulted in reduced washout and a build-up of low-altitude pollutants. While a subset was chosen for these analyses to reduce the quantity of data presented, the results and differences between chemical schemes are indicative of simulations across a longer period from 14 to 30 July 2010.

Time series of key oxidants over the 4 days are shown in Fig. 2. The data are of ground-level concentrations, over the entire domain minus the outer 10 grid cells. Median $\mathrm{O}_{3}$ levels are almost identical in both simulations. As CRIv2-R5 is expected to produce similar ozone levels to the full MCM, this is in effect a strong validation of the simpler CBM-Z ability to produce realistic $\mathrm{O}_{3}$ levels. However, peaks in maximum ozone, shown by the track of the 95th percentile, are slightly higher in CRIv2-R5, indicating that more production is occurring in some regions. The distributions of this extra production and implications of it will be discussed below. Nighttime $\mathrm{NO}_{3}$ concentrations are consistently higher in the CRIv2-R5, with median concentrations almost twice as high during the pollution episode.

Maximum daytime $\mathrm{OH}$ concentrations between the schemes are very similar, although there is somewhat more nighttime $\mathrm{OH}$ in CRIv2-R5. The increased $\mathrm{OH}$ and $\mathrm{NO}_{3}$ in 
Table 7. Approximate mappings of MOZART-4 VOCs to CBM-Z and CRIv2-R5 mechanisms used in WRF-Chem runs. Based on Table 7 of Emmons et al. (2010); the total number of carbon bonds are conserved between mappings of the two schemes, with added PAR and OLT bonds passed to CBM-Z where approximate mappings need to be made (after Zaveri and Peters, 1999).

\begin{tabular}{lll}
\hline MOZART-4 & CBM-Z & CRIv2-R5 \\
\hline CH4 & CH4 & CH4 \\
C2H6 & ETH & C2H6 \\
C3H8 & $3 \times$ PAR & C3H8 \\
BIGALK & $5 \times$ PAR & $1.25 \times$ NC4H10 \\
C2H4 & OL2 & C2H4 \\
C3H6 & OLT + PAR & C3H6 \\
BIGENE & OLI $+2 \times$ PAR & TBUT2ENE \\
TOLUENE & TOL & TOLUENE \\
ISOP & ISO & C5H8 \\
C10H16 & $2 \times$ ISO & $0.67 \times$ APINENE \\
& & $+0.33 \times$ BPINENE \\
CH3OH & CH3OH & CH3OH \\
C2H5OH & C2H5OH & C2H5OH \\
CH2O & HCHO & HCHO \\
CH3CHO & ALD & CH3CHO \\
CH3COOH & ORA2 & CH3CO2H \\
GLYALD & ALD & HOCH2CHO \\
CH3OOH & CH3OOH & OP1 \\
CH3COOOH & & PAA \\
CH3COCH3 & KET & KET \\
HYAC & KET & KET \\
CH3COCHO & MGLY & \\
CH3COOH & & CH3CO2H \\
MEK & KET + PAR & MEK \\
PAN & PAN & PAN \\
MPAN & PAN + OLT & MPAN \\
CRESOL & CSL & OXYL \\
\hline & & \\
\hline
\end{tabular}

the CRIv2-R5 run should result in higher nighttime oxidative capacity; this will be discussed further in Sect. 4.2.

Figure 3 shows ground-level mixing ratios of $\mathrm{NO}, \mathrm{NO}_{2}$, $\mathrm{O}_{3}$ and $\mathrm{OH}$, plus the ratio of VOCs to $\mathrm{NO}_{\mathrm{x}}$, for midday on 19 July 2010. $\mathrm{NO}_{2}$ levels and VOC: $\mathrm{NO}_{\mathrm{x}}$ ratios are similar in both schemes. However, there is considerably less daytime NO over mainland Europe in CRIv2-R5. Here, the large quantity of VOCs produce $\mathrm{RO}_{2}$ as they are oxidised. These react with $\mathrm{NO}$ to produce $\mathrm{NO}_{2}$. The longer, more explicit chemical breakdown of VOCs in CRIv2-R5 produces more $\mathrm{RO}_{2}$, depleting $\mathrm{NO}$ and producing net $\mathrm{O}_{3}$. This results in approximately 5 ppbv more ground-level midday $\mathrm{O}_{3}$ over mainland Europe in CRIv2-R5.

Low VOC : $\mathrm{NO}_{\mathrm{x}}$ ratios occur along the shipping lanes over the North Atlantic, English Channel and North Sea, due to the high $\mathrm{NO}_{\mathrm{x}}$ and low VOC content of shipping emissions (see Fig. 1). In these regions, $\mathrm{O}_{3}$ is depleted, somewhat more so in CRIv2-R5 than CBM-Z. Midday OH concentrations are
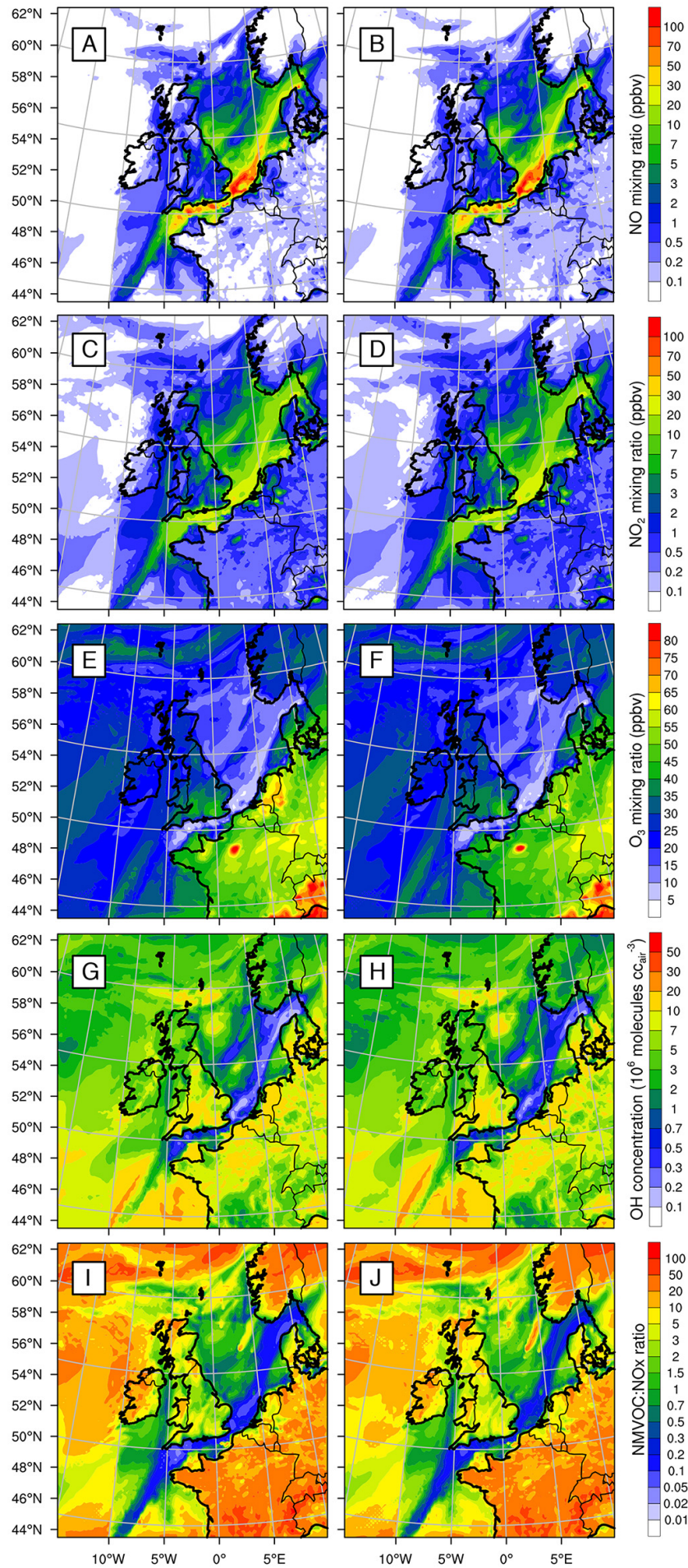

Figure 3. $\mathrm{NO}$ (a and $\mathbf{b}), \mathrm{NO}_{2}(\mathbf{c}$ and $\mathbf{d})$, and $\mathrm{O}_{3}(\mathbf{e}$ and $\mathbf{f})$ mixing ratios, as well as $\mathrm{OH}$ concentrations ( $\mathbf{g}$ and $\mathbf{h}$ ) and the $\mathrm{VOC}: \mathrm{NO}_{\mathrm{x}}$ ratio (i and $\mathbf{j}$ ) in the lowest model level at 12:00 UTC on 19 July 2010. $(\mathbf{a}, \mathbf{c}, \mathbf{e}, \mathbf{g}$ and $\mathbf{i})$ are from the CRIv2-R5 model run; $(\mathbf{b}, \mathbf{d}, \mathbf{f}, \mathbf{h}$ and $\mathbf{j})$ are from the CBM-Z model run. 

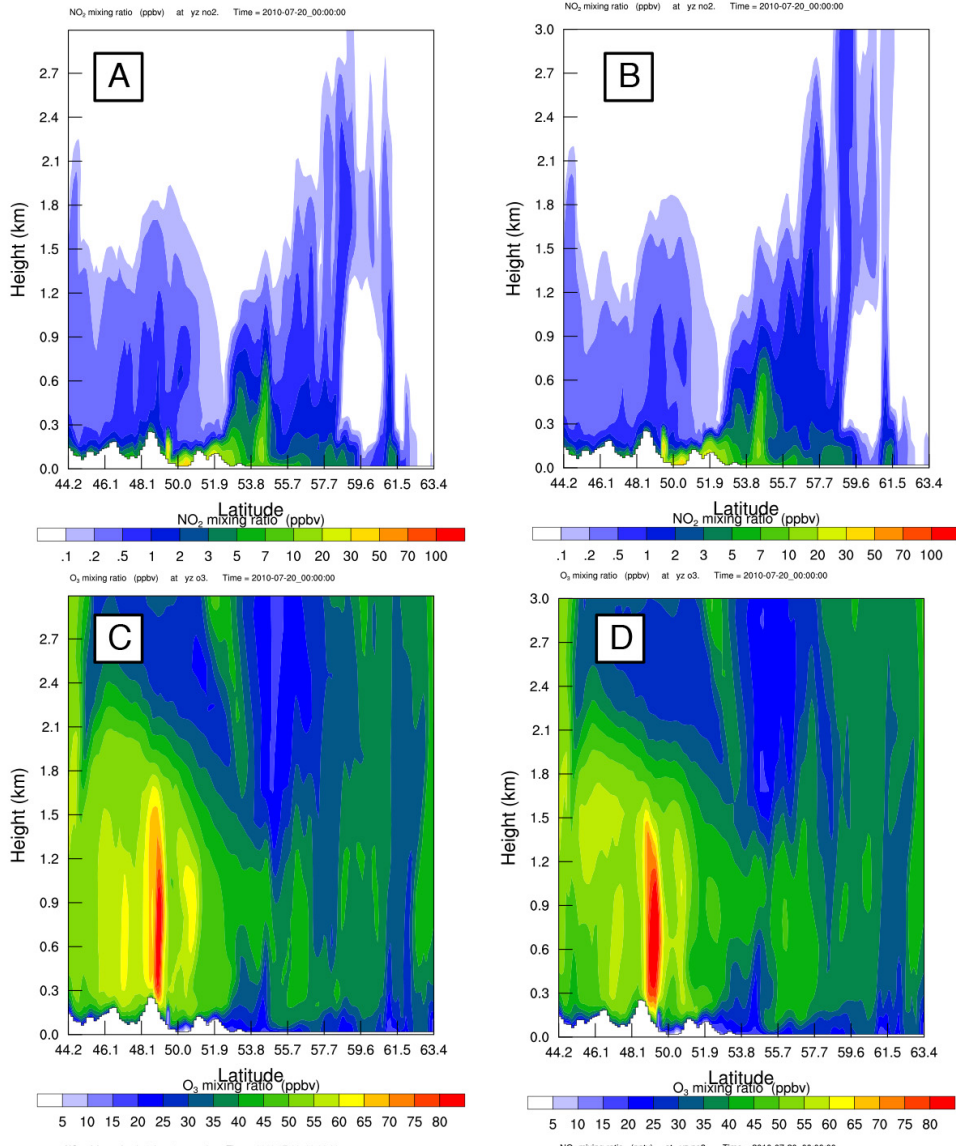

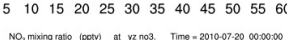

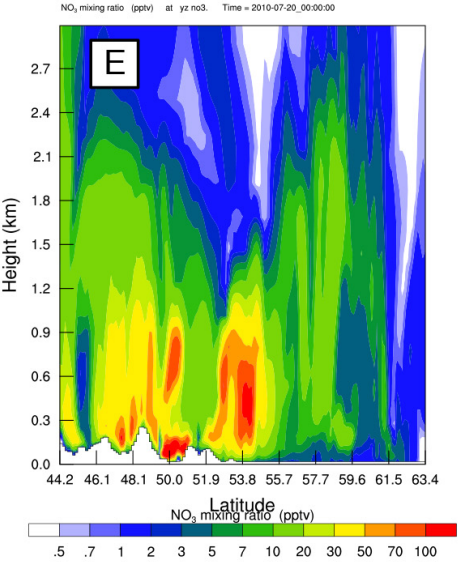

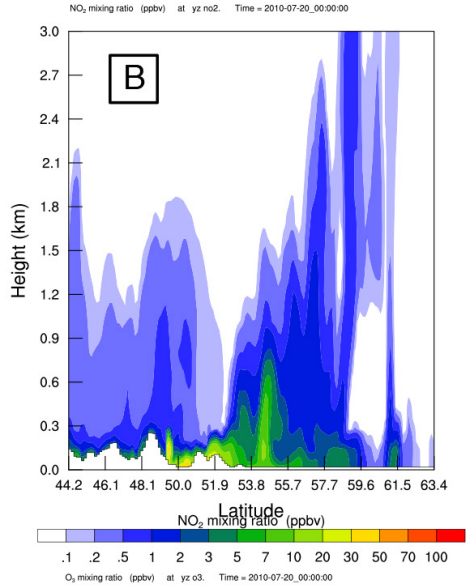

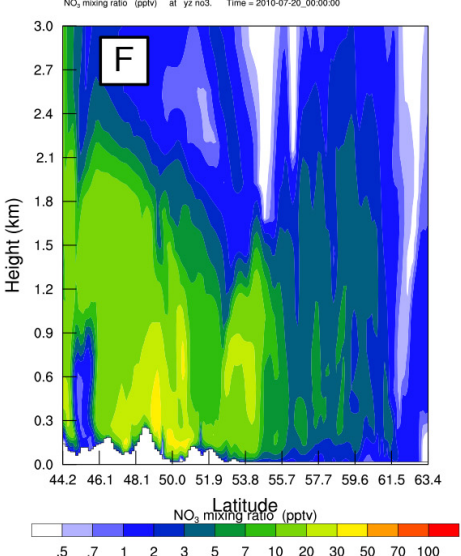

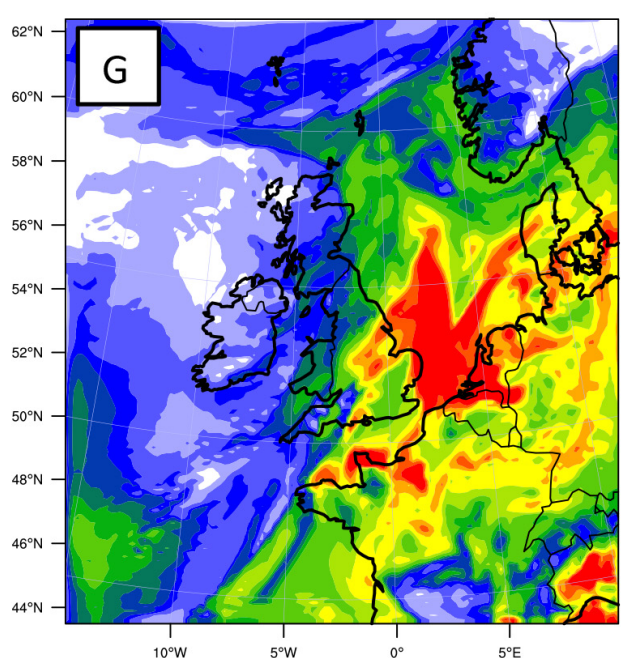

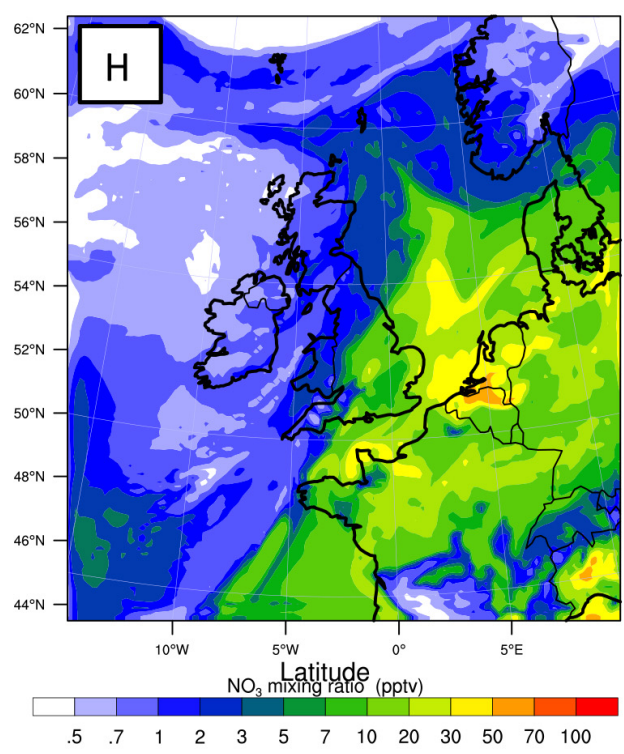

Figure 4. $\mathrm{NO}_{2}$ (a and $\left.\mathbf{b}\right), \mathrm{O}_{3}$ (c and $\mathbf{d}$ ), and $\mathrm{NO}_{3}$ (e and $\mathbf{f}$ ) mixing ratios along a vertical transect through the model domain taken at 00:00 UTC on 20 July 2010. The transect runs roughly south-north through the domain, passing through London $\left(51.5072^{\circ}\right.$ latitude, $0.1275^{\circ}$ longitude). (a, c, and e) are from the CRIv2-R5 model run; (b, d, and f) are from the CBM-Z model run. Panels (g) and (h) show $\mathrm{NO}_{3}$ mixing ratios horizontally interpolated at $300 \mathrm{~m}$ a.g.1. for CRIv2-R5 (g) and CBM-Z (h) runs.

similar in both schemes, showing a correlation with $\mathrm{O}_{3}$, as photolysis of $\mathrm{O}_{3}$ is the main source of $\mathrm{OH}$ production.

Near emission sources of NO, such as over the English Channel, the North Sea and parts of the UK, both $\mathrm{O}_{3}$ and $\mathrm{NO}_{3}$ levels are kept low by reaction with NO. Further downwind, most $\mathrm{NO}_{\mathrm{x}}$ is in the form of $\mathrm{NO}_{2}$ and $\mathrm{O}_{3}$ is not so depleted, providing the conditions for $\mathrm{NO}_{3}$ formation. This is most clearly seen in the vertical profiles (Fig. 4), where maximum $\mathrm{NO}_{3}$ loadings occur in ageing pollution plumes some $300-500 \mathrm{~m}$ a.g.l. Overall the distribution of nighttime $\mathrm{NO}_{3}$ is far more heterogeneous than daytime $\mathrm{OH}$. There is consistently more $\mathrm{NO}_{3}$ produced in CRIv2-R5 compared to CBM$\mathrm{Z}$. This can largely be attributed to the increased reaction rate of the $\mathrm{NO}_{2}$ and $\mathrm{O}_{3}$ reaction and moderately increased night- 

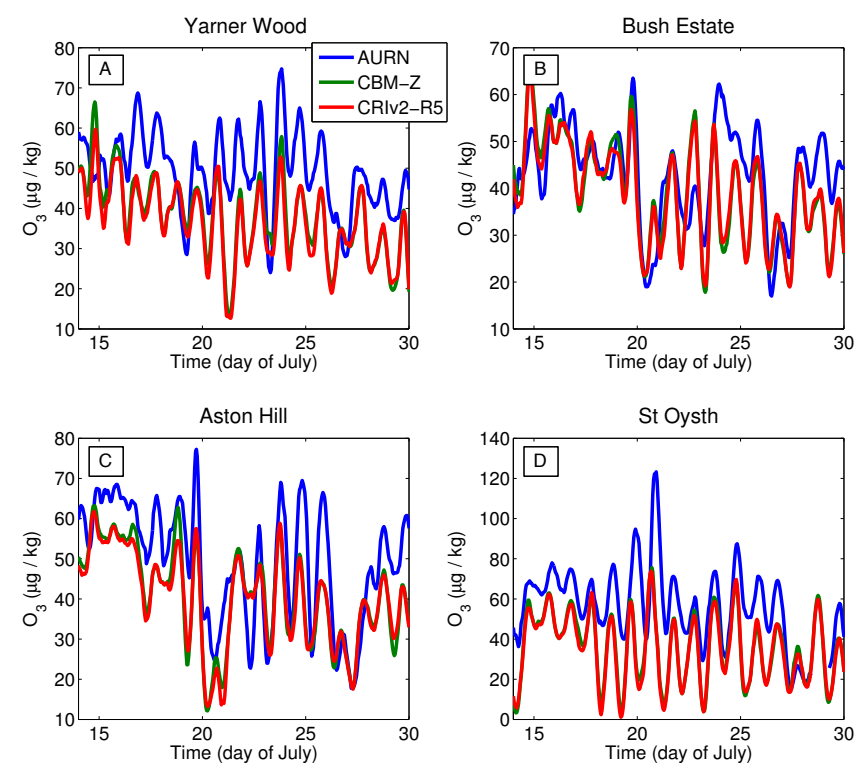

Figure 5. Comparison of $\mathrm{O}_{3} 8 \mathrm{~h}$ means from AURN measurements (blue line) and model predictions (green and red lines for CBM-Z and CRIv2-R5 simulations, respectively). Measurement sites are: (a) Yarner Wood, $50.60^{\circ}$ lat, $-3.72^{\circ}$ lon; (b) Bush Estate, $55.86^{\circ}$ lat, $-3.21^{\circ}$ lon; (c) Aston Hill, $52.50^{\circ}$ lat, $-3.03^{\circ}$ lon; and (d) St Oysth, $51.78^{\circ}$ lat, $1.05^{\circ}$ lon. Statistical information used to generate figure is included in the Supplement.

time concentrations of $\mathrm{O}_{3}$ and $\mathrm{NO}_{2}$ in plumes. Figure 6 focuses on the $48 \mathrm{~h}$ period around 20 July 2010 at $300 \mathrm{~m}$ above ground. In the CRIv2-R5 scenario, $\mathrm{NO}_{2}$ remains constant or increases at night whereas it decreases in CBM-Z. The throughput of this $\mathrm{NO}_{2}$ results in steadily increasing $\mathrm{NO}_{3}$ and $\mathrm{N}_{2} \mathrm{O}_{5}$ in CRIv2-R5, as opposed to the stabilising or slowly decreasing nighttime mixing ratios in CBM-Z.

Limited measurement availability of the short-lived radicals and VOCs makes measurement evaluation of the differences between the CBM-Z and CRIv2-R5 chemical schemes on a regional scale challenging. However, the UK Automatic Urban and Rural Network (AURN; http://uk-air.defra.gov. uk/networks/network-info?view=aurn) provides long-term measurements of $\mathrm{O}_{3}$ and $\mathrm{NO}_{x}$ which can give an indication of the photochemical state of the atmosphere. Comparisons of the $8 \mathrm{~h}$ running mean values of $\mathrm{O}_{3}$ for four sites across the UK between 14-30 July with the CRIv2-R5 and CBM-Z schemes are shown Fig. 5 (similar plots for $\mathrm{NO}_{2}$ and $\mathrm{NO}$, as well as a map of the measurement site locations, are given in the Supplement).

Both model scenario predictions exhibit diurnal cycles roughly similar to those measured. Variations in $\mathrm{O}_{3}$ mixing ratios in the model and measurements are in broad agreement at the Bush Estate (located in central Scotland, $55.86^{\circ} \mathrm{N},-3.21^{\circ} \mathrm{E}$ ) and Aston Hill (central Wales, $52.50^{\circ} \mathrm{N}$, $-3.03^{\circ} \mathrm{E}$ ) measurement sites, although modelled $\mathrm{O}_{3}$ mixing ratios tend to be slightly lower than measurements. At
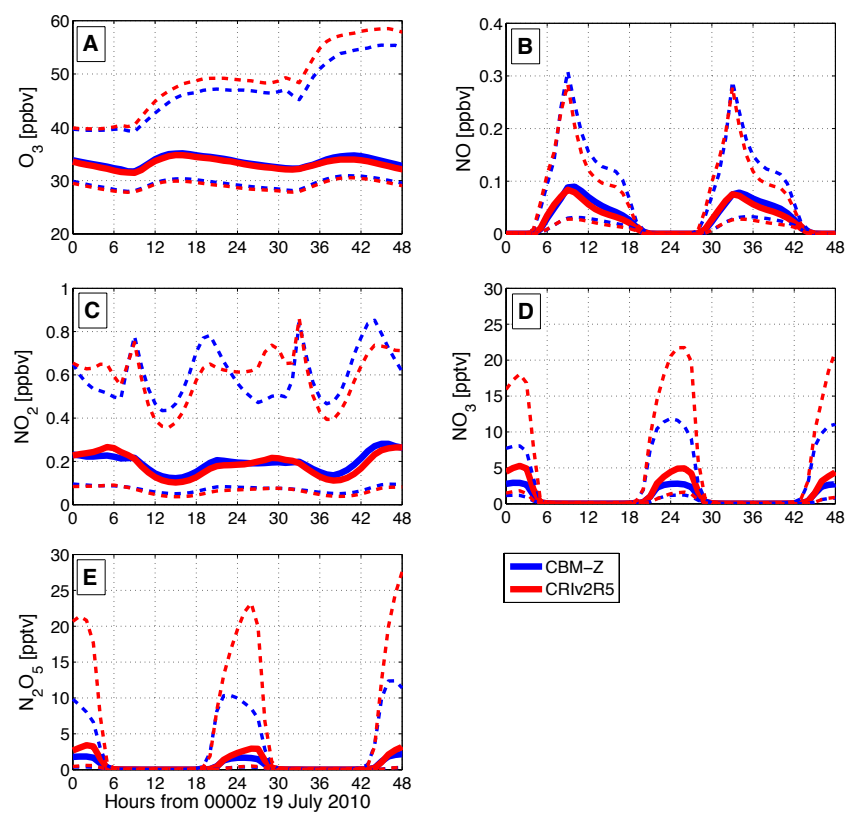

Figure 6. Mixing ratios of $\mathrm{O}_{3}(\mathbf{a}), \mathrm{NO}(\mathbf{b}), \mathrm{NO}_{2}$ (c), $\mathrm{NO}_{3}(\mathbf{d})$ and $\mathrm{N}_{2} \mathrm{O}_{5}$ (e) interpolated at $300 \mathrm{~m}$ a.g.l. over a $48 \mathrm{~h}$ period, starting from 00:00 UTC on 19 July 2010: solid blue line, median from CBM-Z run; solid red line, median from CRIv2-R5; thin dashed lines for 25 th and 75 th percentiles. The statistical information used to generate figure is included in the Supplement.

the Yarner Wood (SW England, $50.60^{\circ} \mathrm{N},-3.72^{\circ} \mathrm{E}$ ) and St Oysth (SE England, $51.78^{\circ} \mathrm{N}, 1.05^{\circ} \mathrm{E}$ ) measurement sites, modelled $\mathrm{O}_{3}$ mixing ratios are consistently lower than the measurements. The similarity between model predictions using the two chemical schemes is very close, much closer than the fit between model predictions and measurements. This is because the relative concentrations of these species is dominated by the photostationary state, as well as errors in emission sources, meteorology or the radiation scheme. As such this comparison is not useful to evaluate which, if either, chemical scheme performs best in these conditions, although it does highlight that further work is needed to improve model representation of the fundamental processes outside the scope of this study.

\subsection{Evaluation of daytime and nighttime oxidation of VOCs}

Figure 7 shows the VOC tendencies with respect to oxidation by ground-level $\mathrm{OH}$ and $\mathrm{NO}_{3}$, for the CRIv2-R5 and CBM-Z chemical schemes. The instantaneous tendencies $(\mathrm{dVOC} / \mathrm{d} t$, molecules $\mathrm{cm}^{-3} \mathrm{~s}^{-1}$ ) for the plots are calculated by summing the number of molecules of VOC species that can react with $\mathrm{OH}$ per unit time and volume:

$\frac{\mathrm{dVOC}}{\mathrm{d} t}_{\mathrm{OH}}=-[\mathrm{OH}] \sum_{i}\left(k_{\mathrm{OH}, i} \times\left[\mathrm{VOC}_{i}\right]\right)$, 

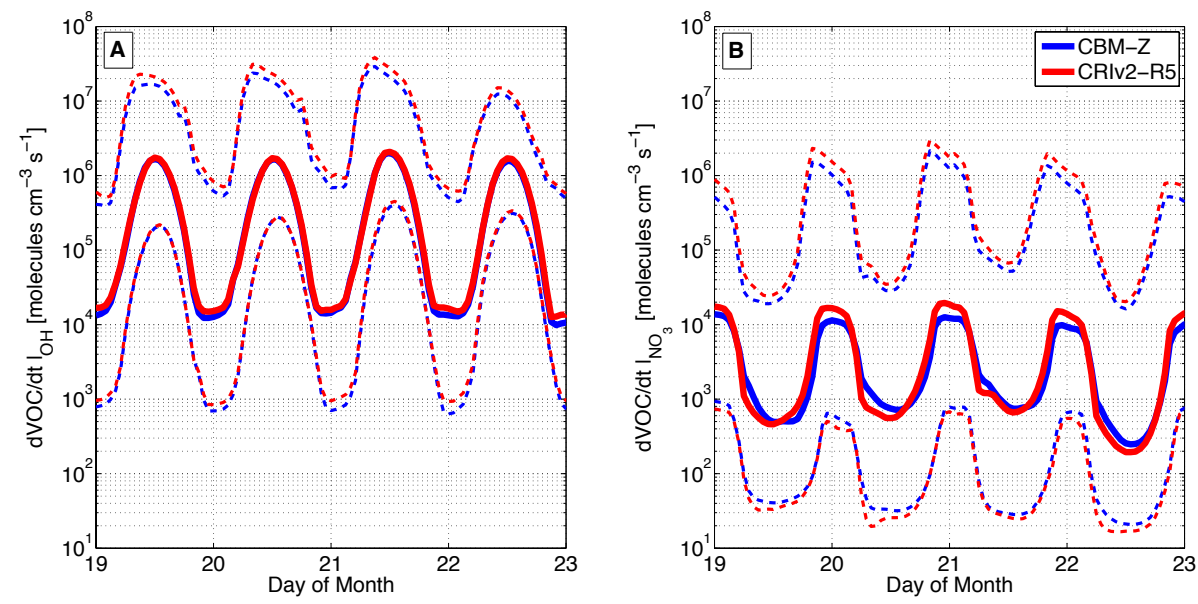

Figure 7. Time series of oxidation rate of VOCs by $\mathrm{OH}$ (a) and $\mathrm{NO}_{3}$ (b). Data from ground level over entire domain, minus the 10 grid points nearest the boundary, covering 4 days between 00:00 UTC on 19 July 2010 and 00:00 UTC on 23 July 2010. Solid blue line: median of CBM-Z run; solid red line: median of CRIv2-R5. Finer dashed lines show 5th and 95th percentiles. The statistical information used to generate figure is included in the Supplement.
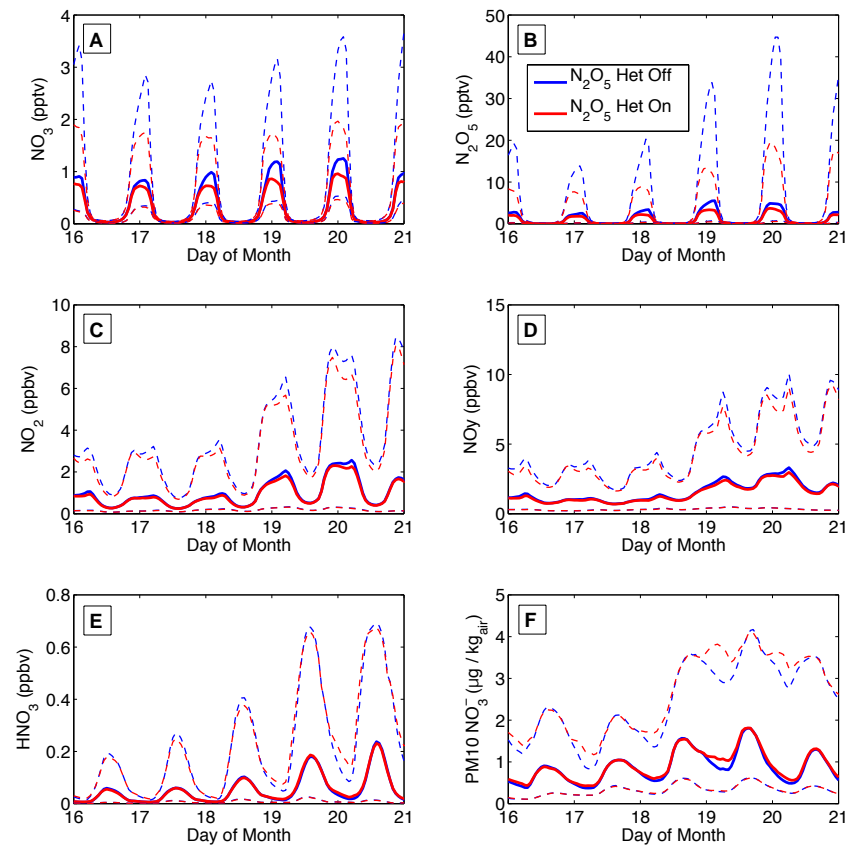

Figure 8. Domain-averaged median (solid lines) and 25th and 75th percentiles (dashed lines) of ground level $\mathrm{NO}_{3}, \mathrm{~N}_{2} \mathrm{O}_{5}, \mathrm{NO}_{2}$, gasphase $\mathrm{NO}_{\mathrm{y}}$, and $\mathrm{HNO}_{3}$ mixing ratios, as well as $\mathrm{PM}_{10} \mathrm{NO}_{3}^{-}$mass loadings, for the model runs without (blue lines) and with (red lines) $\mathrm{N}_{2} \mathrm{O}_{5}$ heterogeneous uptake scheme are shown in $(\mathbf{a}-\mathbf{f})$ respectively. The statistical information used to generate figure is included in the Supplement. where $k_{\mathrm{OH}, i}$ is the reaction rate of [VOC] $]_{i}$ with $\mathrm{OH}$ and may be temperature and/or pressure dependent. Reaction rates were taken from the KPP files for the relevant mechanisms and so differ slightly between CRIv2-R5 and CBM-Z. Some errors were found for three reaction rates within the released version of the CRIv2-R5 scheme in WRF-Chem v3.5.1, as is described in Appendix B and the Supplement. The corrected rates were used for calculations of tendencies. An equivalent equation to Eq. (10) was used for $\mathrm{NO}_{3}$, using respective rates for $\mathrm{NO}_{3}$ and each VOC species it can react with.

$\mathrm{NO}_{3}$ oxidation of VOCs is important during the night, but it should be noted that the $\mathrm{OH}$ oxidation of VOCs is still nonnegligible during this period; indeed the rates for this are comparable to those for $\mathrm{NO}_{3}$-driven oxidation. While daytime $\mathrm{OH}$ oxidation is similar in both schemes, nighttime $\mathrm{NO}_{3}$ oxidation is slightly higher in CRIv2-R5, owing to the higher $\mathrm{NO}_{3}$ levels in CRIv2-R5 (see Fig. 2). The greater spatial heterogeneity of $\mathrm{NO}_{3}$ compared to $\mathrm{OH}$ skews the results somewhat. Maximum $\mathrm{NO}_{3}$ levels are around $300 \mathrm{~m}$ above ground, with low $\mathrm{NO}_{3}$ at ground level. However, most reactive VOCs are near source at ground level. The lower, more stable nighttime boundary layer plays a role here, preventing transport of fresh VOC emissions higher in the troposphere, while maintaining high $\mathrm{NO}$ levels, and low $\mathrm{NO}_{3}$ at the ground. Thus the dynamics of the nighttime atmosphere are also a factor in making $\mathrm{OH}$ a more significant oxidant than $\mathrm{NO}_{3}$.

When looking at the whole VOC population, oxidation via $\mathrm{OH}$ pathways dominate over $\mathrm{NO}_{3}$ pathways. However, some species of VOC preferentially react with $\mathrm{NO}_{3}$ over $\mathrm{OH}$. Of particular interest are those species containing double carbon bonds, such as anthropogenic propene $\left(\mathrm{C}_{3} \mathrm{H}_{6}\right)$ or biogenic isoprene $\left(\mathrm{C}_{5} \mathrm{H}_{8}\right)$, which react with $\mathrm{NO}_{3}$ to form organic nitrates $\left(\mathrm{RONO}_{2}\right)$. While daytime oxidation via $\mathrm{OH}$ is still 

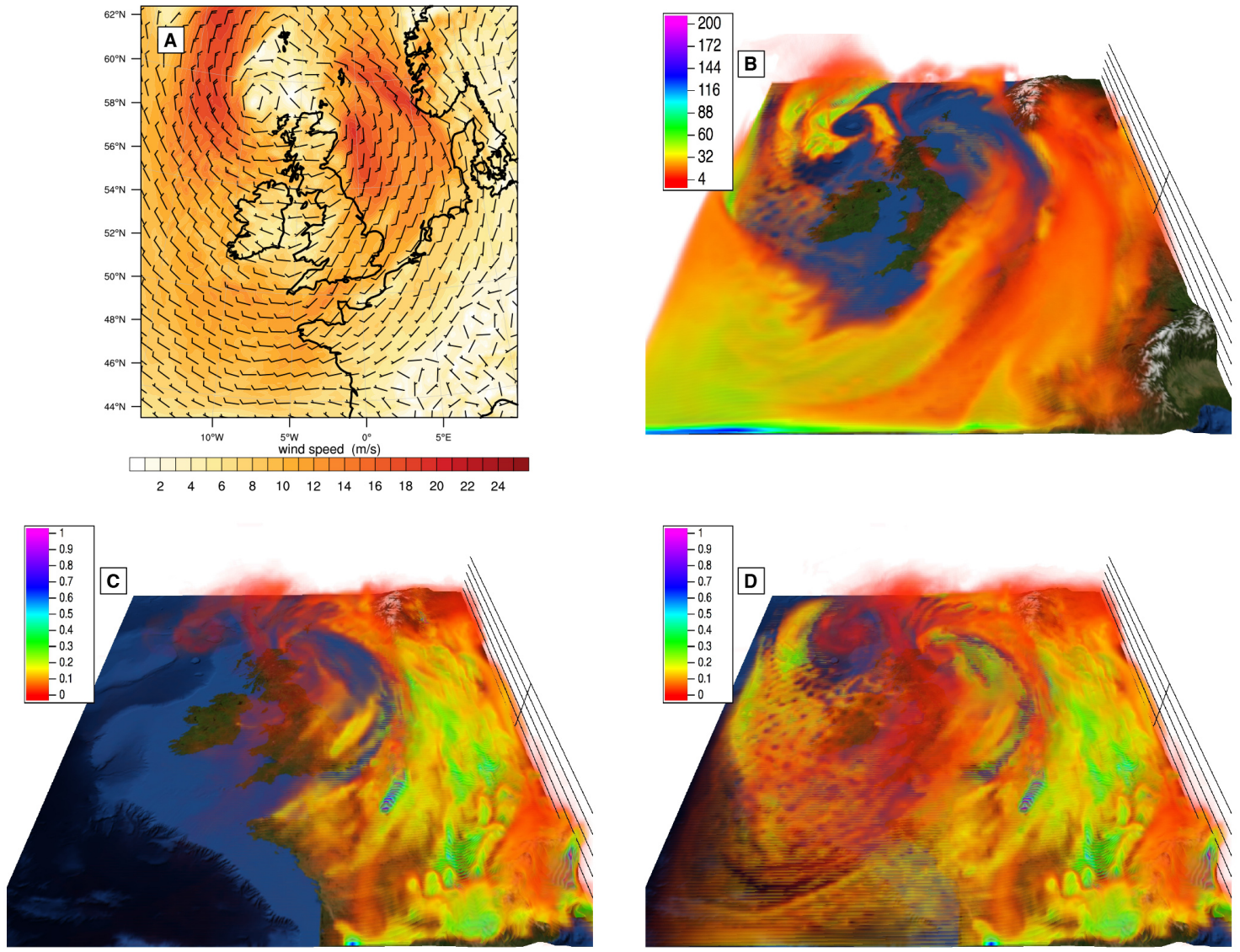

Figure 9. Wind fields and aerosol mass loadings at 12:00 UTC on 16 July 2010: (a) ground-level wind speeds and vectors; (b) PM 10 sea-salt aerosol mass loadings, increasing in opacity from completely transparent at $4 \mu \mathrm{g} \mathrm{kg}_{\text {air }}^{-1}$; (c) and (d) total organic aerosol mass loadings for low biogenic activity and high biogenic activity runs respectively, with opacity increasing from completely transparent at $0 \mu \mathrm{g} \mathrm{kg}$ air . (b-d) generated using VAPOR (Clyne et al., 2007). Vertical scale is shown by the axis on the right of each panel, each line indicates a $1000 \mathrm{~m}$ increase in altitude.

higher, at nighttime more double bonds are broken through reaction with $\mathrm{NO}_{3}$ than $\mathrm{OH}$.

\section{3 $\quad \mathrm{N}_{2} \mathrm{O}_{5}$ heterogeneous uptake}

Across the domain the effect of $\mathrm{N}_{2} \mathrm{O}_{5}$ heterogeneous chemistry is to increase the processing of $\mathrm{NO}_{\mathrm{x}}$ to generate $\mathrm{HNO}_{3}$ and aerosol nitrate. The median nighttime mixing ratios of $\mathrm{NO}_{3}$ and $\mathrm{N}_{2} \mathrm{O}_{5}$ are reduced by up to $30 \%$ (flattening the peak in these mixing ratios observed around $06: 00 \mathrm{~h}$ without the heterogeneous processing) (see Fig. 8a and b). Reduction of mixing ratios within pollution plumes is greater, with the 75 th percentile mixing ratios being reduced by up to $70 \%$. The build-up of $\mathrm{NO}_{2}$ and gas-phase $\mathrm{NO}_{\mathrm{y}}$ across the domain during the night is reduced only slightly - again the greatest effect is in the pollution plumes (Fig. $8 \mathrm{c}$ and d). The majority of $\mathrm{HNO}_{3}$ and aerosol nitrate is formed during the day, through the $\mathrm{OH}+\mathrm{NO}_{2}$ pathway; nighttime production through $\mathrm{N}_{2} \mathrm{O}_{5}$ heterogeneous chemistry adds to this (espe- cially during the pollution episode from 19 to 21 July) but does not dominate (Fig. 8e and f).

The spatial distribution of gas-phase $\mathrm{NO}_{3}$, at $00: 00 \mathrm{~h}$ on the 20 July, can be seen in Fig. 4e and g. The plumes of pollution rising up over the North Sea from the UK and mainland Europe are clearly visible. An animation of the evolution of $\mathrm{NO}_{3}$ mixing ratios, both with and without $\mathrm{N}_{2} \mathrm{O}_{5}$ heterogeneous chemistry, over the centre of the domain, from 16 to 20 July, is included in the Supplement (in this animation $\mathrm{NO}_{3}$ data is only plotted for mixing ratios greater than 30 pptv). In the animation it is clear that $\mathrm{NO}_{3}$ mixing ratios are generally suppressed by the inclusion of $\mathrm{N}_{2} \mathrm{O}_{5}$ heterogeneous chemistry. This is most obvious over the UK and shipping channels through the English Channel (where $\mathrm{NO}_{3}$ mixing ratios increase from $<30 \mathrm{pptv}$ to $40-90 \mathrm{pptv}$ with the removal of $\mathrm{N}_{2} \mathrm{O}_{5}$ heterogeneous chemistry), but can also be seen in the widespread increase of $\mathrm{NO}_{3}$ mixing ratios over the North Sea. 

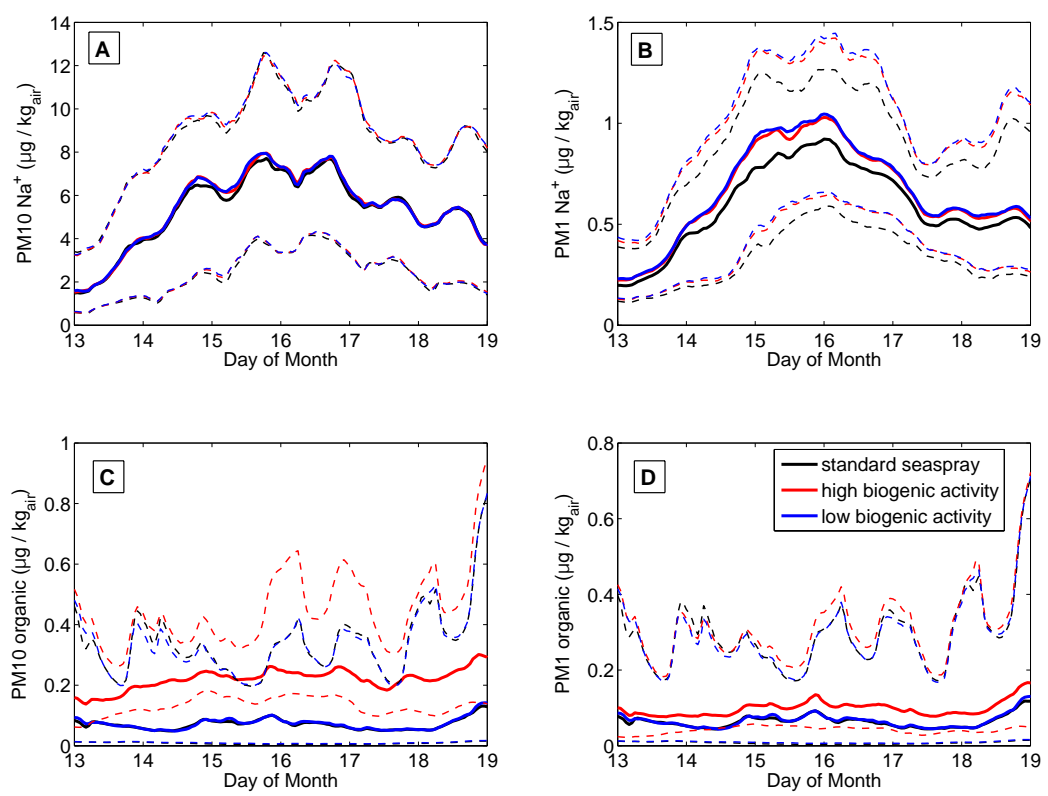

Figure 10. Domain averaged median (solid lines) and 25th and 75th percentiles (dashed lines) of ground level $\mathrm{PM}_{10} \mathrm{Na}^{+}, \mathrm{PM}_{1} \mathrm{Na}^{+}, \mathrm{PM}_{10}$ organics, and $\mathrm{PM}_{1}$ organics mass loadings are shown in (a-d) respectively, starting from 00:00 UTC on 13 July 2010 . Values for model runs made with the original sea-spray scheme, by the new scheme with high biogenic activity, and by the new scheme with low biogenic activity (see text) are represented by black, red and blue lines respectively. The statistical information used to generate figure is included in the Supplement.

More in-depth analysis of the influence of $\mathrm{N}_{2} \mathrm{O}_{5}$ heterogeneous chemistry will be presented in the companion modelmeasurement comparison paper (Lowe et al., 2014).

\subsection{Marine aerosol emissions}

A cyclonic weather system (with surface winds of up to $24 \mathrm{~m} \mathrm{~s}^{-1}$, see Fig. 9a) passed across the UK between 15 and 17 July 2010. The increase in production of sea-spray aerosol is visible in the median $\mathrm{PM}_{10} \mathrm{Na}^{+}$mass loadings in the lowest model level, which increase from 3 to $7 \mu \mathrm{g} \mathrm{kg}_{\text {air }}^{-1}$ during this period (Fig. 10a). To investigate the new sea-spray routine we have run two scenarios using it: one representing low biogenic activity, and a second representing higher biogenic activity. These scenarios have been run without OC in the boundary conditions, in order to focus just on contributions to OC from local sea-spray and anthropogenic emissions. We will compare these with the base model run described above.

Whole-domain median, and 25th and 75th percentile, values (calculated as described above) are shown in Fig. 10 for $\mathrm{Na}^{+}$(representing the sea-salt content of the aerosol population) and (primary) organics (from both sea-spray and anthropogenic aerosol). The total sea-salt aerosol mass loading is not significantly changed by the new parameterisation (represented by $\mathrm{PM}_{10} \mathrm{Na}^{+}$in Fig. 10a) due to the dominance of the larger particles on the mass distribution.

The new parameterisation changes the source term for seaspray aerosol in size bins 1 to 4 , and so it is in $\mathrm{PM}_{1}$ size range that $\mathrm{Na}^{+}$mass loadings increase, by up to $20 \%$ when the wind speeds are high (Fig. 10b). The organic content of $\mathrm{PM}_{10}$ and $\mathrm{PM}_{1}$ aerosol (Fig. 10c and d, respectively) are very similar between the original scheme (black lines) and low biogenic activity scenario (blue lines), as would be expected by the mass fractionation of emissions in that scenario (Table 2). The differences between these scenarios and the high biogenic activity scenario (red lines) indicate the proportion of organic aerosol which comes from sea-spray emissions (as opposed to anthropogenic sources).

In the high-biogenic activity scenario sea-spray emissions increase the background, unpolluted, $\mathrm{PM}_{10}$ organic content (represented by the median and 25th percentile lines in Fig. 10c) by $0.1-0.2 \mu \mathrm{g} \mathrm{kg}_{\text {air }}^{-1}$. The increase in $\mathrm{PM}_{10}$ organic mass loadings within polluted regions (represented by the 75 th percentile lines) is proportionally lower when the seaspray emissions are low (such as on 14 and 15 July). However, during periods of high wind speeds, as observed on 16 and $17 \mathrm{July}$, this contribution increases to $0.2-0.3 \mu \mathrm{g} \mathrm{kg}_{\text {air }}^{-1}$, almost doubling the (primary) organic aerosol mass loadings within these polluted regions. Figure $9 \mathrm{c}$ and $\mathrm{d}$ show the change in distribution across the domain due to these emissions, highlighting a significant increase in organic aerosol across the North Atlantic in the high-biogenic activity scenario. An animation showing the same for the period of the 14 th through to the 17 th July is included in the Supplement. 


\section{Conclusions}

In this study we have presented several developments made to WRF-Chem to make the model more suitable for studying nighttime chemical processes over the UK.

The first was to add a detailed organic gas-phase scheme (CRIv2-R5), traceable to the MCM v3.1, to WRF-chem using the KPP protocol. This scheme was compared against the existing CBM-Z in a test case over northern Europe. Whilst there was slightly more ozone production in the CRIv2-R5 model in highly polluted regions, average $\mathrm{O}_{3}$ mixing ratios were comparable in both schemes. There was significantly more production of $\mathrm{NO}_{3}$ in pollution plumes at night a few hundred metres a.g.1. in the CRIv2-R5 model. Oxidation via $\mathrm{OH}$ channels are around 3 orders of magnitude greater than via $\mathrm{NO}_{3}$ during the day, whereas at night the two pathways are of a similar magnitude. VOC tendencies with respect to $\mathrm{NO}_{3}$ oxidation are higher in the CRIv2-R5 scheme, due to the higher $\mathrm{NO}_{3}$ concentrations.
An $\mathrm{N}_{2} \mathrm{O}_{5}$ heterogeneous chemistry parameterisation was added to the MOSAIC aerosol module, based on Bertram and Thornton (2009). This was coupled to the CRIv2-R5 and CBM-Z chemical schemes. It has been shown to significantly reduce the build-up of $\mathrm{NO}_{3}$ and $\mathrm{N}_{2} \mathrm{O}_{5}$ through the night. Inclusion of the effects of organic aerosol and comparisons with measurement data from the RONOCO flight campaign are made in the companion paper to verify the effectiveness of the parameterisation (Lowe et al., 2014).

Finally, we added a new sea-spray source term which extends down to $3 \mathrm{~nm}$ particle size and allows the addition of an organic fraction to the source term. This was tested for low and high biogenic activity scenarios, and was shown to greatly increase the mass of organic aerosol over the ocean in windy conditions, although organic particulate mass is still small relative to sea-salt aerosol loadings.

The developments have been released in version 3.5.1 of WRF-Chem (available for download from http://www.mmm. ucar.edu/wrf/users/). 


\section{Appendix A: CBM-Z changes}

In order to facilitate comparison between CBM-Z and CRIv2-R5 we modified CBM-Z by adding the DMS chemistry scheme of von Glasow and Crutzen (2004) (as was done for CRIv2-R5). In addition, a dummy reaction for $\mathrm{ClNO}_{2}$ was added to the scheme in order that the full $\mathrm{N}_{2} \mathrm{O}_{5}$ heterogeneous scheme could be used with CBM-Z (see below). Two changes have also been made to the reaction scheme to update the $\mathrm{NO}_{3}$ and $\mathrm{N}_{2} \mathrm{O}_{5}$ chemistry, bringing this more in line with the most recent recommendations (Atkinson et al., 2004) (see http://www.iupac-kinetic.ch.cam.ac.uk/ for latest evaluated data).

1. The $\mathrm{NO}_{3}+\mathrm{HO}_{2}$ reaction rate has been increased to $4 \times 10^{-12} \mathrm{~cm}^{3}$ molecules ${ }^{-1} \mathrm{~s}^{-1}$ and the products are now just $\mathrm{OH}$ and $\mathrm{NO}_{2}$. (Rate last evaluated on 16 August 2008, $\mathrm{OH}$ and $\mathrm{NO}_{2}$ pathway thought to dominate, although branching ratios are uncertain; http://www.iupac-kinetic.ch.cam.ac.uk/datasheets/ pdf/NOx18_HO2_NO3.pdf).

2. The $\mathrm{N}_{2} \mathrm{O}_{5}+\mathrm{H}_{2} \mathrm{O} \rightarrow 2 \mathrm{HNO}_{3}$ reaction has been removed (recommendation not to include in models until further field or lab experiments are available; http://www.iupac-kinetic.ch.cam.ac.uk/datasheets/pdf/ NOx33_N2O5_H2O.pdf).

\section{Appendix B: Additions to WRF-Chem}

The majority of the developments detailed in this paper have been included in WRF-Chem version 3.5.1: the CRIv2-R5 chemical scheme; $\mathrm{N}_{2} \mathrm{O}_{5}$ heterogeneous chemistry; new seaspray emission schemes; and emission speciation for the Northwest European domain. Since the release of WRFChem 3.5.1 we have corrected the calculations for three reaction rates in the code for CRIv2-R5. Details of these changes, as well as the replacement KPP equation and definition files for WRF-Chem 3.5.1, are included in the Supplement. Below we list the namelist options to use these developments.

The new chemistry mechanism options are:

chem_opt=600. CRIv2-R5 chemical mechanism,

chem_opt=601. CRIv2-R5 chemical mechanism with 8-bin MOSAIC aerosol including some aqueous reactions,

chem_opt=611. CRIv2-R5 chemical mechanism with 4-bin MOSAIC aerosol including some aqueous reactions.
The new emission scheme options are:

emiss_opt=19. CRIv2-R5 gas-phase emissions, emiss_opt=20. CRIv2-R5/MOSAIC emissions (configured for UK aerosol distributions),

emiss_inpt_opt=121. UK aerosol emission size fractionation for MOSAIC.

One new namelist flag has been added to WRF-Chem to control the $\mathrm{N}_{2} \mathrm{O}_{5}$ heterogeneous scheme, and which is set once for all domains:

n2o5_hetchem $=0$. no $\mathrm{N}_{2} \mathrm{O}_{5}$ heterogeneous chemistry (default),

n2o5_hetchem $=1 . \mathrm{N}_{2} \mathrm{O}_{5}$ heterogeneous chemistry without $\mathrm{Cl}^{-}$pathway,

n2o5_hetchem $=2$. full inorganic $\mathrm{N}_{2} \mathrm{O}_{5}$ heterogeneous chemistry scheme.

To use this scheme you have to select a chemistry option which includes the MOSAIC aerosol module, and which carries $\mathrm{N}_{2} \mathrm{O}_{5}$ and $\mathrm{ClNO}_{2}$ in the gas-phase. The intermediate option (which does not take into consideration the chloride content of the aerosol) is provided for use where $\mathrm{ClNO}_{2}$ is not included in the gas-phase scheme.

The new sea-spray emission scheme options are:

seas_opt $=3$. example low biogenic activity sea-spray emissions,

seas_opt $=4$. example high biogenic activity sea-spray emissions.

These include the example settings used for this study. Users wishing to use different organic concentrations and fractionations can do this by editing the definitions of the oc02um, org_frac_low_activity and org_frac_high_activity parameters in chem/module_mosaic_addemiss.F. 


\section{The Supplement related to this article is available online at doi:10.5194/gmd-7-2557-2014-supplement.}

Acknowledgements. S. Archer-Nicholls was supported by a Nature Environment Research Council (NERC) quota studentship, work funded on the RONOCO NERC grant NE/F004656/1. R. Zaveri and J. Fast were supported by the US Department of Energy (DOE) Atmospheric System Research (ASR) program at PNNL. PNNL is operated by the US DOE by Battelle Memorial Institute. $\varnothing$. Hodnebrog has received funding from the European Union's Seventh Framework Programme (FP7/2007-2013) under Grant Agreement no. 212095 (CityZen). H. Denier van der Gon was partly funded by the EU Seventh Research Framework Programme (grant agreement No. 283576, MACC II). Our thanks to Thomas Pugh from KIT for help with developing the emissions processing script; Stacy Walters from UCAR for reworking the mozbc script for use with MACC boundary conditions; and Johannes Kaiser from ECMWF for help acquiring and processing MACC boundary conditions data. Model runs were carried out on the High End Computing Terascale Resources (HECToR) British national supercomputer.

Edited by: R. Sander

\section{References}

Ackermann, I. J., Hass, H., Memmesheimer, M., Ebel, A., Binkowski, F. S., and Shankar, U.: Modal aerosol dynamics model for Europe: development and first applications, Atmos. Environ., 32, 2981-2999, 1998.

Allan, B. J., McFiggans, G., and Plane, J. M. C., Coe, H., and McFadyen, G. G.: The nitrate radical in the remote marine boundary layer, J. Geophys. Res., 105, 24191-24204, doi:10.1029/2000JD900314, 2000.

Allan, J. D., Williams, P. I., Morgan, W. T., Martin, C. L., Flynn, M. J., Lee, J., Nemitz, E., Phillips, G. J., Gallagher, M. W., and Coe, H.: Contributions from transport, solid fuel burning and cooking to primary organic aerosols in two UK cities, Atmos. Chem. Phys., 10, 647-668, doi:10.5194/acp-10-647-2010, 2010.

Asaf, D., Tas, E., Pedersen, D., Peleg, M., and Luria, M.: Longterm measurements of $\mathrm{NO}_{3}$ radical at a semiarid urban site: 2 . Seasonal trends and loss mechanisms, Environ. Sci. Technol., 44, 5901-5907, doi:10.1021/es100967z, 2010.

Atkinson, R.: Atmospheric chemistry of VOCs and $\mathrm{NO}_{\mathrm{x}}$, Atmos. Environ., 34, 2063-2101, doi:10.1016/S1352-2310(99)00460-4, 2000 .

Atkinson, R., Baulch, D. L., Cox, R. A., Crowley, J. N., Hampson, R. F., Hynes, R. G., Jenkin, M. E., Rossi, M. J., and Troe, J.: Evaluated kinetic and photochemical data for atmospheric chemistry: Volume $\mathrm{I}-$ gas phase reactions of $\mathrm{O}_{\mathrm{x}}, \mathrm{HO}_{\mathrm{x}}, \mathrm{NO}_{\mathrm{x}}$ and $\mathrm{SO}_{\mathrm{x}}$ species, Atmos. Chem. Phys., 4, 1461-1738, doi:10.5194/acp-41461-2004, 2004.

Baklanov, A., Mahura, A., and Sokhi, R. S. (Eds.): Integrated Systems of Meso-Meteorological and Chemical Transport Models, Springer-Verlag, Berlin, Heidelberg, doi:10.1007/978-3-64213980-2, 2011.
Beck, V., Gerbig, C., Koch, T., Bela, M. M., Longo, K. M., Freitas, S. R., Kaplan, J. O., Prigent, C., Bergamaschi, P., and Heimann, M.: WRF-Chem simulations in the Amazon region during wet and dry season transitions: evaluation of methane models and wetland inundation maps, Atmos. Chem. Phys., 13, 7961-7982, doi:10.5194/acp-13-7961-2013, 2013.

Benedetti, A., Morcrette, J.-J., Boucher, O., Dethof, A., Engelen, R. J., Fisher, M., Flentje, H., Huneeus, N., Jones, L., Kaiser, J. W., Kinne, S., Mangold, A., Razinger, M., Simmons, A. J., and Suttie, M.: Aerosol analysis and forecast in the European Centre for Medium-Range Weather Forecasts Integrated Forecast System: 2. Data assimilation, J. Geophys. Res., 114, D13205, doi:10.1029/2008JD011115, 2009.

Bertram, T. H. and Thornton, J. A.: Toward a general parameterization of $\mathrm{N}_{2} \mathrm{O}_{5}$ reactivity on aqueous particles: the competing effects of particle liquid water, nitrate and chloride, Atmos. Chem. Phys., 9, 8351-8363, doi:10.5194/acp-9-8351-2009, 2009.

Brown, S. S. and Stutz, J.: Nighttime radical observations and chemistry, Chem. Soc. Rev., 41, 6405-6447, doi:10.1039/c2cs35181a, 2012.

Carter, W. P. L.: Development of ozone reactivity scales for volatile organic-compounds, J. Air Waste Manage., 44, 881-899, 1994.

Carter, W. P. L.: Implementation of the SAPRC-99 chemical mechanism into the models-3 framework, US EPA report, available at: http://www.engr.ucr.edu/ carter/pubs/s99mod3.pdf (last access: 17 January 2014), 2000

Chang, W. L., Bhave, P. V., Brown, S. B., Riemer, N., Stutz, J., and Dabdub, D.: Heterogeneous atmospheric chemistry, ambient measurements, and model calculations of $\mathrm{N}_{2} \mathrm{O}_{5}$ : a review, Aerosol Sci. Tech., 45, 665-695, 2011.

Chin, M., Rood, R. B., Lin, S.-J., Müller, J.-F., and Thompson, A. M.: Atmospheric sulfur cycle simulated in the global model GOCART: model description and global properties, J. Geophys. Res., 105, 24671-24687, doi:10.1029/2000JD900384, 2000.

Clyne, J., Mininni, P., Norton, A., and Rast, M.: Interactive desktop analysis of high resolution simulations: application to turbulent plume dynamics and current sheet formation, New J. Phys., 9, 301, doi:10.1088/1367-2630/9/8/301, 2007.

Damian, V., Sandu, A., Damian, M., Potra, F., and Carmichael, G. R.: The Kinetic PreProcessor KPP - a software environment for solving chemical kinetics, Comput. Chem. Eng., 26, 1567-1579, 2002.

Díaz, A. M., Díaz, J. P., Expósito, F. J., Hernández-Leal, P. A., Savoie, D., and Querol, X.: Air masses and aerosols chemical components in the free troposphere at the subtropical northeast Atlantic region, J. Atmos. Chem., 53, 63-90, 2006.

Dee, D. P., Uppala, S. M., Simmons, A. J., Berrisford, P., Poli, P., Kobayashi, S., Andrae, U., Balmaseda, M. A., Balsamo, G., Bauer, P., Bechtold, P., Beljaars, A. C. M., van de Berg, L., Bidlot, J., Bormann, N., Delsol, C., Dragani, R., Fuentes, M., Geer, A. J., Haimberger, L., Healy, S. B., Hersbach, H., Hólm, E. V., Isaksen, L., Kållberg, P., Köhler, M., Matricardi, M., McNally, A. P., Monge-Sanz, B. M., Morcrette, J.-J., Park, B.K., Peubey, C., de Rosnay, P., Tavolato, C., Thépaut, J.-N., and Vitart, F.: The ERA-Interim reanalysis: configuration and performance of the data assimilation system, Q. J. Roy. Meteor. Soc., 137, 553-597, doi:10.1002/qj.828, 2011. 
Department for Environment, Food and Rural Affairs (DEFRA).: Fine Particulate Matter $\left(\mathrm{PM}_{2.5}\right)$ in the UK, Air Quality Expert Group, pb13837, available at: https://www.gov.uk/government/ publications/fine-particulate-matter-pm2-5-in-the-uk (last access: 17 January 2014), 2012.

de Leeuw, G., Andreas, E. L., Anguelova, M. D., Fairall, C. W., Lewis, E. R., O'Dowd, C., Schulz, M., and Schwartz, S. E.: Production flux of sea spray aerosol, Rev. Geophys., 49, 1-39, doi:10.1029/2010RG000349, 2011.

Denier van der Gon, H. A. C., Visschedijk, A., van der Brugh, H., and Dröge, R.: A high resolution European emission data base for the year 2005, a contribution to UBA - Projekt PAREST: Particle Reduction Strategies, TNO report TNO-034-UT-201001895_RPT-ML, Utrecht, 2010.

Dentener, F. J. and Crutzen, P. J.: Reaction of $\mathrm{N}_{2} \mathrm{O}_{5}$ on tropospheric aerosols - impact on the global distribution of $\mathrm{NO}_{\mathrm{x}}, \mathrm{O}_{3}$, and $\mathrm{OH}$, J. Geophys. Res., 98, 7149-7163, 1993.

DeMore, W. B., Sander, S. P., Golden, D. M., Hampson, R. F., Kurylo, M. J., Howard, C. J., Ravishankara, A. R., Kolb, C. E., Molina, M. J.: Chemical Kinetics and Photochemical Data for Use in Stratospheric Modeling, Eval. 12. NASA Jet Propul. Lab., Calif. Inst. of Technol., Pasadena, 1997.

Derwent, R. G.: The long range transport of ozone within Europe and its control, Environ. Pollut., 63, 299-318, 1990.

Dore, C. J., Goodwin, J. W. L., Watterson, J. D., Murrells, T. P., Passant, N. R., Hobson, M. M., Haigh, K. E., Baggott, G., Thistlethwaite, G., Pye, S. T., Coleman, P. J., and King, K. R.: UK emissions of air pollutants 1970-2001, National atmospheric emissions inventory report, AEAT/ENV/R/1593, 1-85580-033-0, 2003.

EMEP: Transboundary Acidification, Eutrophication and Ground Level Ozone in Europe, Norwegian Meteorological Institute, Report 1/2003, 2003.

Emmons, L. K., Walters, S., Hess, P. G., Lamarque, J.-F., Pfister, G. G., Fillmore, D., Granier, C., Guenther, A., Kinnison, D., Laepple, T., Orlando, J., Tie, X., Tyndall, G., Wiedinmyer, C., Baughcum, S. L., and Kloster, S.: Description and evaluation of the Model for Ozone and Related chemical Tracers, version 4 (MOZART-4), Geosci. Model Dev., 3, 43-67, doi:10.5194/gmd3-43-2010, 2010.

Fast, J. D., Gustafson, W. I., Easter, R. C., Zaveri, R. A., Barnard, J. C., Chapman, E. G., Grell, G. A., and Peckham, S. E.: Evolution of ozone, particulates, and aerosol direct radiative forcing in the vicinity of Houston using a fully coupled meteorology-chemistry-aerosol model, J. Geophys. Res., 111, 1-29, doi:10.1029/2005JD006721, 2006.

Forkel, R., Werhahn, J., Hansen, A. B., McKeen, S., Peckham, S., Grell, G., and Suppan, P.: Effect of aerosol-radiation feedback on regional air quality - a case study with WRF-Chem, Atmos. Environ., 53, 202-211, doi:10.1016/j.atmosenv.2011.10.009, 2012.

Fuchs, N. A. and Sutugin, A. G.: High-dispersed aerosols, in: Topics in Current Aerosol Research (Part 2), edited by: Hidy, G. M. and Brock, J. R., Elsevier, New York, 1-200, 1971.

Fuentes, E., Coe, H., Green, D., de Leeuw, G., and McFiggans, G.: On the impacts of phytoplankton-derived organic matter on the properties of the primary marine aerosol - Part 1: Source fluxes, Atmos. Chem. Phys., 10, 9295-9317, doi:10.5194/acp-10-92952010, 2010.
Fuentes, E., Coe, H., Green, D., and McFiggans, G.: On the impacts of phytoplankton-derived organic matter on the properties of the primary marine aerosol - Part 2: Composition, hygroscopicity and cloud condensation activity, Atmos. Chem. Phys., 11, 25852602, doi:10.5194/acp-11-2585-2011, 2011.

Giorgi, F.: Regional climate modeling: status and perspectives, J. Phys. IV, 139, 101-118, doi:10.1051/jp4:2006139008, 2006.

Goldstein, A. H., and Galbally, I. E.: Known and unexplored organic constituents in the Earth's atmosphere, Environ. Sci. Technol., 41, 1514-1521, 2007.

Gong, S. L.: A parameterization of sea-salt aerosol source function for sub- and super-micron particles, Global Biogeochem. Cy., 17, 1097, doi:10.1029/2003GB002079, 2003.

Gong, S. L., Bartie, L. A., and Blanchet, J.-P.: Modeling sea-salt aerosols in the atmosphere 1. Model development, J. Geophys. Res., 102, 3805-3818, 1997.

Grell, G. A., Peckham, S. E., Schmitz, R., McKeen, S. A., Frost, G., Skamarock, W. C., and Eder, B.: Fully coupled "online" chemistry within the WRF model, Atmos. Environ., 39, 6957-6975, doi:10.1016/j.atmosenv.2005.04.027, 2005.

Grell, G. A., Freitas, S. R., Stuefer, M., and Fast, J.: Inclusion of biomass burning in WRF-Chem: impact of wildfires on weather forecasts, Atmos. Chem. Phys., 11, 5289-5303, doi:10.5194/acp11-5289-2011, 2011.

Grosjean, D. and Seinfeld, J. H.: Parameterization of the formation potential of secondary organic aerosols, Atmos. Environ., 23, 1733-1747, 1989.

Guenther, A., Hewitt, C. N., Erickson, D., Fall, R., Geron, C., Graedel, T., Harley, P., Klinger, L., Lerdau, M., Mckay, W. A., Pierce, T., Scholes, B., Steinbrecher, R., Tallamraju, R., Taylor, J., and Zimmerman, P.: A global model of natural volatile organic compound emissions, J. Geophys. Res., 100, 8873-8892, doi:10.1029/94JD02950, 1995.

Guenther, A., Karl, T., Harley, P., Wiedinmyer, C., Palmer, P. I., and Geron, C.: Estimates of global terrestrial isoprene emissions using MEGAN (Model of Emissions of Gases and Aerosols from Nature), Atmos. Chem. Phys., 6, 3181-3210, doi:10.5194/acp-63181-2006, 2006.

Hodnebrog, Ø., Stordal, F., and Berntsen, T. K.: Does the resolution of megacity emissions impact large scale ozone?, Atmos. Environ., 45, 6852-6862, doi:10.1016/j.atmosenv.2011.01.012, 2011.

Hodnebrog, Ø., Solberg, S., Stordal, F., Svendby, T. M., Simpson, D., Gauss, M., Hilboll, A., Pfister, G. G., Turquety, S., Richter, A., Burrows, J. P., and Denier van der Gon, H. A. C.: Impact of forest fires, biogenic emissions and high temperatures on the elevated Eastern Mediterranean ozone levels during the hot summer of 2007, Atmos. Chem. Phys., 12, 8727-8750, doi:10.5194/acp-12-8727-2012, 2012.

Inness, A., Baier, F., Benedetti, A., Bouarar, I., Chabrillat, S., Clark, H., Clerbaux, C., Coheur, P., Engelen, R. J., Errera, Q., Flemming, J., George, M., Granier, C., Hadji-Lazaro, J., Huijnen, V., Hurtmans, D., Jones, L., Kaiser, J. W., Kapsomenakis, J., Lefever, K., Leitão, J., Razinger, M., Richter, A., Schultz, M. G., Simmons, A. J., Suttie, M., Stein, O., Thépaut, J.-N., Thouret, V., Vrekoussis, M., Zerefos, C., and the MACC team: The MACC reanalysis: an $8 \mathrm{yr}$ data set of atmospheric composition, Atmos. Chem. Phys., 13, 4073-4109, doi:10.5194/acp-13-4073-2013, 2013. 
Jacobson, M. Z. and Ginnebaugh, D. L.: Global-through-urban nested three-dimensional simulation of air pollution with a 13,600-reaction photochemical mechanism, J. Geophys. Res., 115, D14304, doi:10.1029/2009JD013289, 2010

Jenkin, M. E, Saunders, S. M., Derwent, R. G., and Pilling, M. J.: Development of a reduced speciated VOC degradation mechanism for use in ozone models, Atmos. Environ., 36, 4725-4734, 2002.

Jenkin, M. E., Saunders, S. M., Wagner, V., and Pilling, M. J.: Protocol for the development of the Master Chemical Mechanism, MCM v3 (Part B): tropospheric degradation of aromatic volatile organic compounds, Atmos. Chem. Phys., 3, 181-193, doi:10.5194/acp-3-181-2003, 2003.

Jenkin, M., Watson, L., Utembe, S., and Shallcross, D.: A Common Representative Intermediates (CRI) mechanism for VOC degradation. Part 1: Gas phase mechanism development, Atmos. Environ., 42, 7185-7195, doi:10.1016/j.atmosenv.2008.07.028, 2008.

Kettle, A. J., Andreae, M. O., Amouroux, D., Andreae, T. W., Bates, T. S., Berresheim, H., Bingemer, H., Boniforti, R., Curran, M. A. J., DiTullio, G. R., Helas, G., Jones, G. B., Keller, M. D., Kiene, R. P., Leck, C., Levasseur, M., Malin, G., Maspero, M., Matrai, P., McTaggart, A. R., Mihalopoulos, N., Nguyen, B. C., Novo, A., Putaud, J. P., Rapsomanikis, S., Roberts, G., Schebeske, G., Sharma, S., Simó, R., Staubes, R., Turner, S., and Uher, G.: A global database of sea surface dimethylsulfide (DMS) measurements and a procedure to predict sea surface DMS as a function of latitude, longitude, and month, Global Biogeochem. Cy., 13, 399-444, 1999.

Kulmala, M., Asmi, A., Lappalainen, H. K., Baltensperger, U., Brenguier, J.-L., Facchini, M. C., Hansson, H.-C., Hov, Ø., O'Dowd, C. D., Pöschl, U., Wiedensohler, A., Boers, R., Boucher, O., de Leeuw, G., Denier van der Gon, H. A. C., Feichter, J., Krejci, R., Laj, P., Lihavainen, H., Lohmann, U., McFiggans, G., Mentel, T., Pilinis, C., Riipinen, I., Schulz, M., Stohl, A., Swietlicki, E., Vignati, E., Alves, C., Amann, M., Ammann, M., Arabas, S., Artaxo, P., Baars, H., Beddows, D. C. S., Bergström, R., Beukes, J. P., Bilde, M., Burkhart, J. F., Canonaco, F., Clegg, S. L., Coe, H., Crumeyrolle, S., D’Anna, B., Decesari, S., Gilardoni, S., Fischer, M., Fjaeraa, A. M., Fountoukis, C., George, C., Gomes, L., Halloran, P., Hamburger, T., Harrison, R. M., Herrmann, H., Hoffmann, T., Hoose, C., Hu, M., Hyvärinen, A., Hõrrak, U., Iinuma, Y., Iversen, T., Josipovic, M., Kanakidou, M., Kiendler-Scharr, A., Kirkevåg, A., Kiss, G., Klimont, Z., Kolmonen, P., Komppula, M., Kristjánsson, J.-E., Laakso, L., Laaksonen, A., Labonnote, L., Lanz, V. A., Lehtinen, K. E. J., Rizzo, L. V., Makkonen, R., Manninen, H. E., McMeeking, G., Merikanto, J., Minikin, A., Mirme, S., Morgan, W. T., Nemitz, E., O’Donnell, D., Panwar, T. S., Pawlowska, H., Petzold, A., Pienaar, J. J., Pio, C., Plass-Duelmer, C., Prévôt, A. S. H., Pryor, S., Reddington, C. L., Roberts, G., Rosenfeld, D., Schwarz, J., Seland, Ø., Sellegri, K., Shen, X. J., Shiraiwa, M., Siebert, H., Sierau, B., Simpson, D., Sun, J. Y., Topping, D., Tunved, P., Vaattovaara, P., Vakkari, V., Veefkind, J. P., Visschedijk, A., Vuollekoski, H., Vuolo, R., Wehner, B., Wildt, J., Woodward, S., Worsnop, D. R., van Zadelhoff, G.-J., Zardini, A. A., Zhang, K., van Zyl, P. G., Kerminen, V.-M., Carslaw, K., and Pandis, S. N.: General overview: European Integrated project on Aerosol Cloud Climate and Air Quality interactions (EUCAARI) - integrating aerosol research from nano to global scales, Atmos. Chem. Phys., 11, 13061-13143, doi:10.5194/acp11-13061-2011, 2011.

Lee, J. D., McFiggans, G., Allan, J. D., Baker, A. R., Ball, S. M., Benton, A. K., Carpenter, L. J., Commane, R., Finley, B. D., Evans, M., Fuentes, E., Furneaux, K., Goddard, A., Good, N., Hamilton, J. F., Heard, D. E., Herrmann, H., Hollingsworth, A., Hopkins, J. R., Ingham, T., Irwin, M., Jones, C. E., Jones, R. L., Keene, W. C., Lawler, M. J., Lehmann, S., Lewis, A. C., Long, M. S., Mahajan, A., Methven, J., Moller, S. J., Müller, K., Müller, T., Niedermeier, N., O’Doherty, S., Oetjen, H., Plane, J. M. C., Pszenny, A. A. P., Read, K. A., Saiz-Lopez, A., Saltzman, E. S., Sander, R., von Glasow, R., Whalley, L., Wiedensohler, A., and Young, D.: Reactive Halogens in the Marine Boundary Layer (RHaMBLe): the tropical North Atlantic experiments, Atmos. Chem. Phys., 10, 10311055, doi:10.5194/acp-10-1031-2010, 2010.

Liu, D., Allan, J., Corris, B., Flynn, M., Andrews, E., Ogren, J., Beswick, K., Bower, K., Burgess, R., Choularton, T., Dorsey, J., Morgan, W., Williams, P. I., and Coe, H.: Carbonaceous aerosols contributed by traffic and solid fuel burning at a polluted rural site in Northwestern England, Atmos. Chem. Phys., 11, 1603-1619, doi:10.5194/acp-11-1603-2011, 2011.

Liu, X., Easter, R. C., Ghan, S. J., Zaveri, R., Rasch, P., Shi, X., Lamarque, J.-F., Gettelman, A., Morrison, H., Vitt, F., Conley, A., Park, S., Neale, R., Hannay, C., Ekman, A. M. L., Hess, P., Mahowald, N., Collins, W., Iacono, M. J., Bretherton, C. S., Flanner, M. G., and Mitchell, D.: Toward a minimal representation of aerosols in climate models: description and evaluation in the Community Atmosphere Model CAM5, Geosci. Model Dev., 5, 709-739, doi:10.5194/gmd-5-709-2012, 2012.

Lowe, D., Archer-Nicholls, S., Morgan, W., Allan, J., Utembe, S., Ouyang, B., Aruffo, E., Le Breton, M., Zaveri, R. A., Di Carlo, P., Percival, C., Coe, H., Jones, R., and McFiggans, G.: WRF-chem model predictions of the regional impacts of $\mathrm{N}_{2} \mathrm{O}_{5}$ heterogeneous processes on nighttime chemistry over north-western Europe, Atmos. Chem. Phys. Discuss., 14, 20883 20943, doi:10.5194/acpd-14-20883-2014, 2014.

Monks, P. S.: Gas-phase radical chemistry in the troposphere. Chem. Soc. Rev., 34, 376-395, doi:10.1039/b307982c, 2005.

Morcrette, J.-J., Boucher, O., Jones, L., Salmond, D., Bechtold, P., Beljaars, A., Benedetti, A. Bonet, A., Kaiser, J. W., Razinger, M., Schulz, M., Serrar, S., Simmons, A. J., Sofiev, M., Suttie, M., Tompkins, A. M., and Untch, A.: Aerosol analysis and forecast in the European Centre for Medium-Range Weather Forecasts Integrated Forecast System: forward modeling, J. Geophys. Res., 114, D06206, doi:10.1029/2008JD011235, 2009.

Morgan, W. T., Allan, J. D., Bower, K. N., Highwood, E. J., Liu, D., McMeeking, G. R., Northway, M. J., Williams, P. I., Krejci, R., and Coe, H.: Airborne measurements of the spatial distribution of aerosol chemical composition across Europe and evolution of the organic fraction, Atmos. Chem. Phys., 10, 4065-4083, doi:10.5194/acp-10-4065-2010, 2010.

Ntelekos, A., Smith, J. A., Donner, L., Fast, L. D., Chapman, E. G., Gustafson Jr, W. I., and Krajewski, W. F.: Effect of aerosols on intense convective precipitation in the northeastern US, Q. J. Roy. Meteor. Soc., 135, 1367-1391, 2009. 
O'Dowd, C. D., Smith, M. H., Consterdine, I. E., and Lowe, J. A.: Marine aerosol, sea salt, and the marine sulpher cycle: a short review, Atmos. Environ., 31, 73-80, 1997.

O'Dowd, C. D., Facchini, M. C., Cavalli, F., Ceburnis, D., Mircea, M., Decesari, S., Fuzzi, S., Yoon, Y. J., and Putaud, J.P.: Biogenically driven organic contribution to marine aerosol, Nature, 431, 676-680, doi:10.1038/nature02959, 2004.

Osthoff, H. D., Pilling, M. J., Ravishankara, A. R., and Brown, S. S.: Temperature dependence of the $\mathrm{NO}_{3}$ absorption cross-section above $298 \mathrm{~K}$ and determination of the equilibrium constant for $\mathrm{NO}_{3}+\mathrm{NO}_{2} \leftrightarrow \mathrm{N}_{2} \mathrm{O}_{5}$ at atmospherically relevant conditions, Phys. Chem. Chem. Phys., 9, 5785-5793, doi:10.1039/b709193a, 2007.

Qian, Y., Gustafson Jr, W. I., Leung, L. R., and Ghan, S. J.: Effects of soot-induced snow albedo change on snowpack and hydrological cycle in western United States based on Weather Research and Forecasting chemistry and regional climate simulations, J. Geophys. Res., 114, D03108, doi:10.1029/2008JD011039, 2009.

Riemer, N., Vogel, H., Vogel, B., Schell, B., Ackermann, I., Kessler, C., and Hass, H.: Impact of the heterogeneous hydrolysis of $\mathrm{N}_{2} \mathrm{O}_{5}$ on chemistry and nitrate aerosol formation in the lower troposphere under photosmog conditions, J. Geophys. Res., 108, D04144, doi:10.1029/2002JD002436, 2003.

Riemer, N., Vogel, H., Vogel, B., Anttila, T., Kiendler-Scharr, A., Mentel, T. F.: Relative importance of organic coatings for the heterogeneous hydrolysis of $\mathrm{N}_{2} \mathrm{O}_{5}$ during summer in Europe, $\mathrm{J}$. Geophys. Res., 114, D17307, doi:10.1029/2008JD011369, 2009.

Ritter, M., Müller, M. D., Tsai, M.-Y., and Parlow, E.: Air pollution modeling over very complex terrain: an evaluation of WRFChem over Switzerland for two 1-year periods, Atmos. Res., 132-133, 209-222, 2013.

Sakulyanontvittaya, T., Duhl, T., Wiedinmyer, C., Helmig, D., Matsunaga, S., Potosnak, M., Milford, J., and Guenther, A.: Monoterpene and sesquiterpene emission estimates for the United States, Environ. Sci. Technol., 42, 1623-1629, doi:10.1021/es702274e, 2008.

Sarwar, G., Simon, H., Bhave, P., and Yarwood, G.: Examining the impact of heterogeneous nitryl chloride production on air quality across the United States, Atmos. Chem. Phys., 12, 6455-6473, doi:10.5194/acp-12-6455-2012, 2012.

Saunders, S. M., Jenkin, M. E., Derwent, R. G., and Pilling, M. J.: Protocol for the development of the Master Chemical Mechanism, MCM v3 (Part A): tropospheric degradation of nonaromatic volatile organic compounds, Atmos. Chem. Phys., 3, 161-180, doi:10.5194/acp-3-161-2003, 2003.

Schell, B., Ackermann, I. J., Hass, H., Binkowski, F. S., and Ebel, A.: Modeling the formation of secondary organic aerosol within a comprehensive air quality modeling system, J. Geophys. Res., 106, 28275-28293, 2001.

Sillman, S.: The relation between ozone, $\mathrm{NO}_{\mathrm{x}}$ and hydrocarbons in urban and polluted rural environments. Atmos. Environ., 33, 1821-1845, doi:10.1016/S1352-2310(98)00345-8, 1999.

Simpson, D., Fagerli, H., Jonson, J. E., Tsyro, S., Wind, P., and Tuovinen, J.-P.: Transboundary acidification, eutrophication and ground level ozone in Europe. Part I: Unified EMEP model description, EMEP Rep. 1/2003, 104 pp., Norw. Meteorol. Inst., Oslo, 2003.

Sheehy, P. M., Volkamer, R., Molina, L. T., and Molina, M. J.: Oxidative capacity of the Mexico City atmosphere - Part 2: $\mathrm{A} \mathrm{RO}_{\mathrm{x}}$ radical cycling perspective, Atmos. Chem. Phys., 10, 6993-7008, doi:10.5194/acp-10-6993-2010, 2010.

Skamarock, W. C., Klemp, J. B., Dudhia, J., Gill, D. O., Barker, D. M., Wang, W., and Powers, J. G.: A description of the Advanced Research WRF Version 2, NCAR Tech Notes468+STR, 2005

Solazzo, E., Bianconi, R., Pirovano, G., Matthias, V., Vautard, R., Moran, M. D., Wyat Appel, K., Bessagnet, B., Brandt, J. R., Christensen, J. H., Chemel, C., Coll, I., Ferreira, J., Forkel, R., Francis, X. V., Grell, G., Grossi, P., Hansen, A. B., Miranda, A. I., Nopmongcol, U., Prank, M., Sartelet, K. N., Schaap, M., Silver, J. D., Sokhi, R. S., Vira, J., Werhahn, J., Wolke, R., Yarwood, G., Zhang, J., Rao, S. T., and Galmarini, S.: Operational model evaluation for particulate matter in Europe and North America in the context of AQMEII, Atmos. Environ., 53, 75-92, doi:10.1016/j.atmosenv.2012.02.045, 2012a.

Solazzo, E., Bianconi, R., Vautard, R., Appel, K. W., Moran, M. D., Hogrefe, C., Bessagnet, B., Brandt, J. R., Christensen, J. H., Chemel, C., Coll, I., Denier van der Gon, H., Ferreira, J., Forkel, R., Francis, X. V., Grell, G., Grossi, P., Hansen, A. B., Jeričević, A., Kraljević, L., Miranda, A. I., Nopmongcol, U., Pirovano, G., Prank, M., Riccio, A., Sartelet, K. N., Schaap, M., Silver, J. D., Sokhi, R. S., Vira, J., Werhahn, J., Wolke, R., Yarwood, G., Zhang, J., Rao, S., and Galmarini, S.: Model evaluation and ensemble modelling of surface-level ozone in Europe and North America in the context of AQMEII, Atmos. Environ., 53, 60-74, doi:10.1016/j.atmosenv.2012.01.003, 2012b.

Stein, O., Flemming, J., Inness, A., Kaiser, J. W., Schultz, M. G.: Global reactive gases forecasts and reanalysis in the MACC project, Journal of Integrative Environmental Sciences, 9, 57-70, doi:10.1080/1943815X.2012.696545, 2012.

Stockwell, W. R., Middleton, P., Chang, J. S., and Tang, X.: The second-generation regional acid deposition model chemical mechanism for regional air quality modeling, J. Geophys. Res., 95, 16343-16367, 1990.

Stockwell, W. R., Kirchner, F., Kuhn, M., and Seefeld, S.: A new mechanism for regional atmospheric chemistry modeling, J. Geophys. Res., 102, 25847-25879, doi:10.1029/97JD00849, 1997.

Stockwell, W. R., Lawson, C. V., Saunders, E., and Goliff, W. S.: A review of tropospheric atmospheric chemistry and gas-phase chemical mechanisms for air quality modeling, Atmosphere, 3, 1-32, doi:10.3390/atmos3010001, 2011.

Tavolato, C. and Isaksen, L.: Data Usage and Quality Control for ERA-40, ERA-Interim and the operational ECMWF data assimilation system, ERA report series, ECMWF, Reading, 2011

Thornton, J. A., Braban, C. F., and Abbatt, J. P. D.: $\mathrm{N}_{2} \mathrm{O}_{5}$ hydrolysis on sub-micron organic aerosols: the effects of relative humidity, particle phase, and particle size, Phys. Chem. Chem. Phys., 5, 4593-4603, 2003.

Thornton, J. A, Kercher, J. P., Riedel, T. P., Wagner, N. L., Cozic, J., Holloway, J. S., Dub, W. P., Wolfe, G. M., Quinn, P. K., Middlebrook, A. M., Alexander, B., and Brown, S. S.: A large atomic chlorine source inferred from mid-continental reactive nitrogen chemistry, Nature, 464, 271-274, doi:10.1038/nature08905, 2010.

Tuccella, P., Curci, G., Visconti, G., Bessagnet, B., Menut, L., and Park, R. J.: Modelling of gas and aerosol with WRF-Chem over 
Europe: evaluation and sensitivity study, J. Geophys. Res., 117, D03303, doi:10.1029/2011JD016302, 2012.

Utembe, S. R., Jenkin, M. E., Derwent, R. G., Lewis, A. C., Hopkins, J. R., and Hamilton, J. F.: Modelling the ambient distribution of organic compounds during the August 2003 ozone episode in the southern UK, Faraday Discuss., 130, 311-326, doi:10.1039/b417403h, 2005.

Utembe, S. R., Cooke, M. C., Archibald, A. T., Jenkin, M. E., Derwent, R. G., and Shallcross, D. E.: Using a reduced Common Representative Intermediates (CRIv2-R5) mechanism to simulate tropospheric ozone in a 3-D Lagrangian chemistry transport model, Atmos. Environ., 44, 1609-1622, 2010.

von Glasow, R. and Crutzen, P. J.: Model study of multiphase DMS oxidation with a focus on halogens, Atmos. Chem. Phys., 4, 589608, doi:10.5194/acp-4-589-2004, 2004.
Watson, L. A., Shallcross, D. E., Utembe, S. R., and Jenkin, M. E.: Common Representative Intermediates (CRI) mechanism for VOC degradation. Part 2: Gas phase mechanism reduction, Atmos. Environ., 42, 7196-7204, doi:10.1016/j.atmosenv.2008.07.034, 2008.

Ying, Q. and Li, J.: Implementation and initial application of the near-explicit Master Chemical Mechanism in the 3D Community Multiscale Air Quality (CMAQ) model, Atmos. Environ., 45, 3244-3256, 2011

Zaveri, R. A. and Peters, L. K.: A new lumped structure photochemical mechanism for large-scale applications, J. Geophys. Res. 104, 30387-30415, 1999.

Zaveri, R. A., Easter, R. C., Fast, J. D., and Peters, L. K.: Model for Simulating Aerosol Interactions and Chemistry (MOSAIC), J. Geophys. Res., 113, D13204, doi:10.1029/2007JD008782, 2008. 